\title{
Emerging Role of isomiRs in Cancer: State of the Art and Recent Advances
}

\author{
Veronica Zelli ${ }^{1,2}$, Chiara Compagnoni ${ }^{1}$, Roberta Capelli ${ }^{1}$, Alessandra Corrente ${ }^{1}$, Jessica Cornice ${ }^{1}$, \\ Davide Vecchiotti $^{1}{ }^{(D}$, Monica Di Padova ${ }^{1}$ (D) Francesca Zazzeroni ${ }^{1}$, Edoardo Alesse ${ }^{1,+}$ and \\ Alessandra Tessitore $1,2, *,+$
}

1 Department of Biotechnological and Applied Clinical Sciences, University of L'Aquila, Via Vetoio, 67100 L'Aquila, Italy; veronica.zelli@univaq.it (V.Z.); chiara.compagnoni@univaq.it (C.C.); roberta.capelli@graduate.univaq.it (R.C.); alessandra.corrente@graduate.univaq.it (A.C.); jessica.cornice@graduate.univaq.it (J.C.); davide.vecchiotti@univaq.it (D.V.); monica.dipadova@univaq.it (M.D.P.); francesca.zazzeroni@univaq.it (F.Z.); edoardo.alesse@univaq.it (E.A.)

2 Center for Molecular Diagnostics and Advanced Therapies, University of L'Aquila, Via Petrini, 67100 L'Aquila, Italy

* Correspondence: alessandra.tessitore@univaq.it; Tel.: +39-0862433518; Fax: +39-0862433131

+ These authors contributed equally to the work as co-last authors.

Citation: Zelli, V.; Compagnoni, C.; Capelli, R.; Corrente, A.; Cornice, J.; Vecchiotti, D.; Di Padova, M.;

Zazzeroni, F.; Alesse, E.; Tessitore, A. Emerging Role of isomiRs in Cancer: State of the Art and Recent Advances. Genes 2021, 12, 1447. https://doi.org/ 10.3390/genes12091447

Academic Editor: Italia Di Liegro

Received: 4 August 2021

Accepted: 17 September 2021

Published: 20 September 2021

Publisher's Note: MDPI stays neutral with regard to jurisdictional claims in published maps and institutional affiliations.

Copyright: (c) 2021 by the authors. Licensee MDPI, Basel, Switzerland. This article is an open access article distributed under the terms and conditions of the Creative Commons Attribution (CC BY) license (https:/ / creativecommons.org/licenses/by/ $4.0 /)$.

\begin{abstract}
The advent of Next Generation Sequencing technologies brought with it the discovery of several microRNA (miRNA) variants of heterogeneous lengths and/or sequences. Initially ascribed to sequencing errors/artifacts, these isoforms, named isomiRs, are now considered non-canonical variants that originate from physiological processes affecting the canonical miRNA biogenesis. To date, accurate IsomiRs abundance, biological activity, and functions are not completely understood; however, the study of isomiR biology is an area of great interest due to their high frequency in the human miRNome, their putative functions in cooperating with the canonical miRNAs, and potential for exhibiting novel functional roles. The discovery of isomiRs highlighted the complexity of the small RNA transcriptional landscape in several diseases, including cancer. In this field, the study of isomiRs could provide further insights into the miRNA biology and its implication in oncogenesis, possibly providing putative new cancer diagnostic, prognostic, and predictive biomarkers as well. In this review, a comprehensive overview of the state of research on isomiRs in different cancer types, including the most common tumors such as breast cancer, colorectal cancer, melanoma, and prostate cancer, as well as in the less frequent tumors, as for example brain tumors and hematological malignancies, will be summarized and discussed.
\end{abstract}

Keywords: isomiRs; miRNome; miRNA variants; expression pattern; cancer

\section{Introduction}

MicroRNAs (miRNAs) are small, non-coding RNA molecules able to negatively regulate the expression of target genes at the post-transcriptional level. The first miRNA, named lin-4, was discovered in 1993 in Caenorhabditis elegans [1]; afterward, in C. elegans again, let-7 was described [2]. Later, miRNAs were identified in both invertebrates and vertebrates. Numerous studies thereafter, that focused on unveiling the role of these molecules, highlighted the importance of miRNAs functions in the regulation of fundamental biological processes, such as cell proliferation, growth, apoptosis, and metabolism. Today, more than 1900 annotated precursors are listed in the miRbase database for Homo sapiens (www.mirbase.org, accessed on 20 June 2021). Based on gene annotation, miRNAs show different genomic locations in mammals: in $\mathrm{H}$. sapiens, 52\%, 40\%, and 8\% appear to reside in intergenic, intronic, or exonic regions, respectively [3]. Dysregulation of miRNAs' expression was widely described, gaining high attention, in several human pathological conditions that are of a high impact on public health, such as cardiovascular disease $[4,5]$, 
neurological disease [6], and cancer [7]. Regarding the latter, depending on the fine-tuning role in the post-transcriptional regulation of tumor suppressors or oncogenes, miRNAs have been classified as oncomiRs or tumor suppressor miRs [8]. Furthermore, microRNAs are considered as potentially suitable tissue or circulating non-invasive diagnostic, prognostic, and predictive biomarkers in several pathological conditions, including cancer $[9,10]$. With this regard, miRNAs are thought to be released from tissues by active (exosomes, vesicles) or passive (apoptosis, necrosis) mechanisms into the bloodstream, where they are stable and resistant to endogenous RNase. The stability of miRNA in body fluids can be ascribed to macromolecular complex formation, including association with AGO2 or HDL [11-13], and/or microvesicle/exosome encapsulation [14-17]. Furthermore, the possible use and delivery of miRNAs as therapeutic targets is under investigation [18,19].

Next-generation sequencing (NGS) technology has revolutionized and significantly improved the approach to molecular analyses. The great potential of NGS technology is the ability to massively sequence millions of reads, allowing the simultaneous detection of many variants and different gene expression patterns, using a very low amount of nucleic acids with considerable time and cost reduction [20]. With the advent of NGS technologies, several miRNA variant sequences were detected, initially ascribed to sequencing errors/artifacts [21,22]. However, based on the calculated sequencing error rate, they were encountered more frequently than would be expected [23]. This observation led to the hypothesis that such non-canonical variants in length and sequence, now named isomiRs, originated from physiological processes that affect canonical miRNA biogenesis [24-26]. IsomiRs biological activity and functions are not fully understood, but, given their frequency in the human miRNome and their putative functions in cooperating with the canonical miRNAs or exerting different roles as well $[27,28]$, they are a subject of interest for additional new analyses. Moreover, a study based on bioinformatics data elaboration, revealed that annotation, batch variable (i.e., sequencing platform, plate, sample quality, and sequencing depth) correction and quality control of The Cancer Genome Atlas (TCGA) datasets could help to better estimate the real isomiRs frequency, with a consequently better understanding of their putative biological role in cancer [29]. In this scenario, it is undeniable that further analyses are needed to clarify the role of isomiRs, given not only their potentially relevant role in human diseases but also their putative use as biomarkers. In this review, we summarize the current knowledge about the involvement and possible functions of isomiRs in several types of cancer.

\section{From the Canonical microRNAs to isomiRs' Discovery}

MicroRNAs are short, 19-24 nucleotides in length, non-coding RNA molecules playing a role in negatively regulating translation either by inhibition or target mRNA degradation. In the canonical pathway, pri-miRNAs are produced in the nucleus by Polymerase II. Afterward, the RNase III Drosha, with the microprocessor complex subunit DGCR8 (DiGeorge critical region 8) cleaves pri-miRNAs, thus generating 60-100 nucleotides in length hairpin precursors (pre-miRNAs) which are transferred to the cytoplasm by Exportin 5. There, premiRNAs are cleaved again by the RNase III Dicer, giving rise to mature double-stranded miRNAs which associate to a member of Argonaute (AGO1-2-3-4 paralogs) family proteins to produce the miRISC (miRNA-induced silencing complex), with one strand preserved (guide) and the other one degraded (passenger). MiRNAs effects are principally induced by the interaction between the seed region (nucleotides $2-8$ at the microRNA $5^{\prime}$ end) and specific partially or perfectly complementary microRNA responsive elements (MREs) in the target mRNA, mainly located at the $3^{\prime}$-UTR, leading to translation inhibition or mRNA degradation, respectively $[30,31]$. Complex and not completely understood processes are at the base of the different modalities of gene expression silencing which involve, among other factors, AGO members [32-35]. Even though more in-depth and clarifying analyses are needed, previous studies demonstrated an essential role of AGOs in endonucleolytic cleavage, translation repression, or mRNA destabilization. AGO2 was shown to possess slicer activity, whereas AGO1-3-4 were described to have mainly a slicer-independent activ- 
ity and to play a role in deadenylation and translation repression [36-38]. It is known that a single miRNA can potentially interact with hundreds of target genes and that multiple miRNAs can regulate the same mRNA [39-41]. With this regard, to assist, predict, and assess the complicated network of miRNAs:mRNAs interactions, several bioinformatics approaches [42], algorithms and tools have been designed [43,44].

Usually, microRNAs are characterized by specific sequences. However, in 2007, Landgraf et al. [45] sequenced over 250 small RNA libraries from 26 different organ systems and cell types from humans and rodents and described miRNA variants in approximately $20 \%$ of clone sequences. Similarly, in 2008, Morin et al. [24] observed that miRNAs from human embryonic stem cells frequently showed sequence variations from their canonical form, coining the term isomiR to refer to these multiple variants.

These sequence variations were initially ascribed to post-transcriptional modifications or PCR/sequencing technical errors, but, with the advent of NGS technologies coupled with more sophisticated analysis algorithms, it was demonstrated that such newly discovered variants cannot be considered as technical artifacts, but rather attributable to molecules with in vivo functional and evolutionary importance [28,46].

\section{3. isomiRs' Classification}

IsomiRs are heterogeneous molecules characterized by different nucleotide sequences and/or lengths with respect to their canonical counterparts. As reported by Wu et al. [47], besides the canonical forms and depending on the modification, four classes of isomiRs are identified which include: (1) isomiRs with changes at the $5^{\prime}$ end; (2) isomiRs with changes at the $3^{\prime}$ end; (3) isomiRs showing polymorphisms within the sequence, without any difference in length; (4) isomiRs with polymorphic plus $5^{\prime}$ and / or $3^{\prime}$ changes (mixed type). Extensive classification also identifies three classes for $5^{\prime}$ and $3^{\prime}$ isomiRs which are mutually exclusive: with deletion/addition, both referred to nucleotides at $5^{\prime}$ or $3^{\prime}$ end, and with variations, referred to changes at the level of $5^{\prime}$ or $3^{\prime}$ nucleotides, including extensions of the original length. Moreover, the addition of nucleotides can be further defined as template or non-template, depending on the correspondence of the added nucleotides with the flanking precursor sequence (Figure 1a).

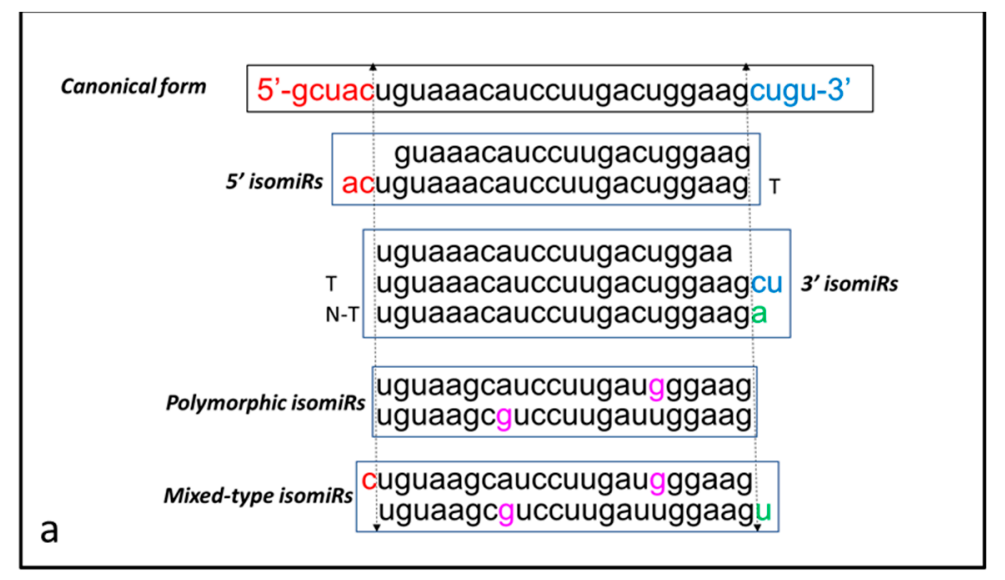

Figure 1. Cont. 


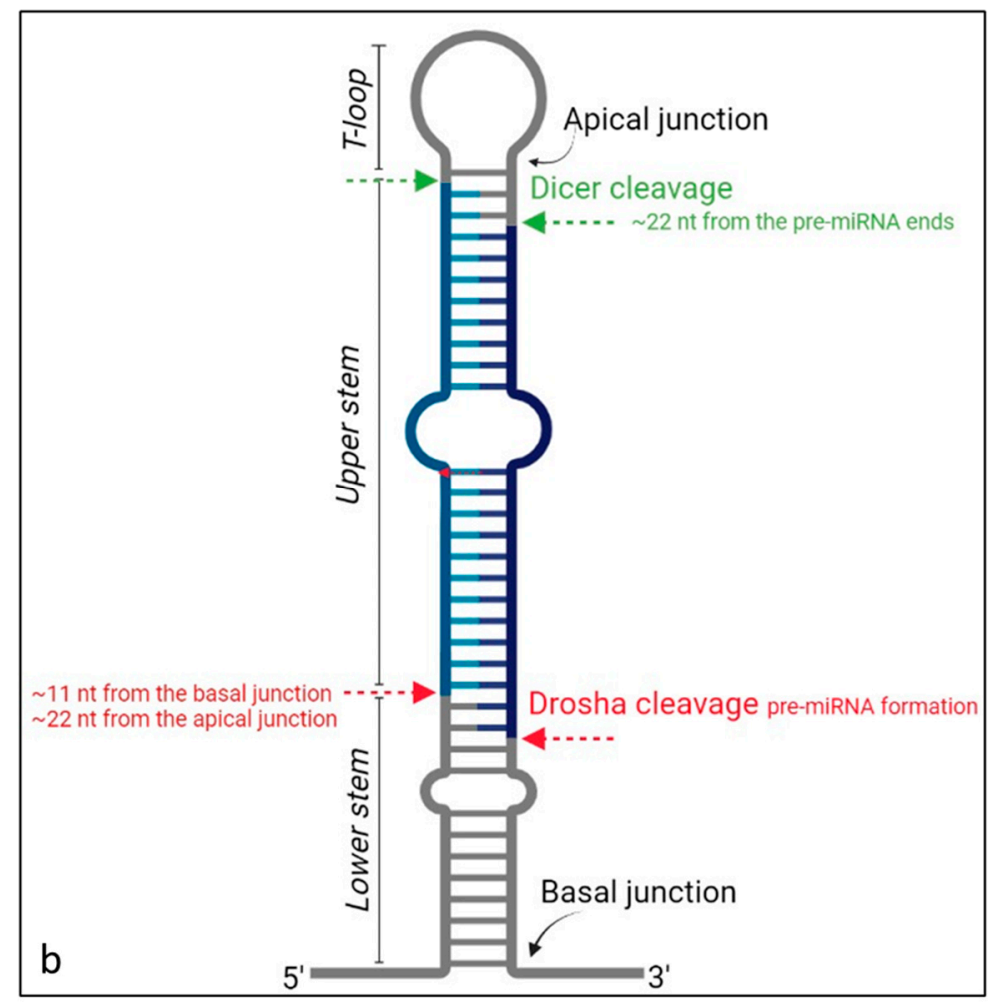

Figure 1. (a) Schematic of isomiRs classification and related modifications compared to the canonical form ( $5^{\prime}$ isomiR, $3^{\prime}$ isomiR, polymorphic and mixed-type isomiRs) (hsa-miR-30e-5p sequence as an example). T: template, N-T: non-template, based on the correspondence of the added nucleotides with the flanking precursor sequence; (b) miRNAs and possible isomiRs biogenesis through sequential cleavages mediated by Drosha and Dicer enzymes (image generated by using BioRender https: / / biorender.com/ accessed on 20 June 2021).

\section{Biogenesis of isomiRs}

IsomiRs can arise from different and not completely understood mechanisms; below the most important are reported.

\subsection{Drosha/Dicer Non-Canonical Cleavage}

In the canonical biogenesis pathway, the miRNA $5^{\prime}$ and $3^{\prime}$ termini are generated by sequential cleavages of the primary transcript mediated by Drosha and Dicer enzymes [48]. Drosha/DGCR8 complex induces a cleavage at the level of specific positions with respect to the basal (approximately 11 nucleotides away) and the apical (approximately 22 nucleotides away) junctions of the pri-miRNA; Subsequently, Dicer recognizes the pre-miRNA termini via the PAZ domain and cuts the short hairpin pre-miRNA in a site located approximately 22 nucleotides away from the $5^{\prime} / 3^{\prime}$ ends, thus removing the terminal loop and generating the duplex miRNA/miRNA* containing guide and passenger strands [49] (Figure 1b). Experimental models suggest that Drosha cleavage imprecision appears related to modification of the pri-miR loop size, or to alterations of the stem length or the single-stranded sequences at its base. Similarly, Dicer cleavage imprecision seems to be dependent on pre$\mathrm{miR}$ structure and sequence (reviewed by Tomasello et al. [26]). In this scenario, cleavage imprecision can generate new $5^{\prime}$ and $3^{\prime}$ variants with possibly different functions [50-52]. Isoforms varying in length can be ascribed, other than to imprecise cleavage, to the removal of the end(s), or to the addition of nucleotides: in the first and second case, template conditions are generated, whereas in the third one a non-template condition generally occurs [25]. Bofill-De Ros et al. [53] analyzed the maturation of three paralogs of pri-miR-9 (pri-miR-9-1/2/3), demonstrating that pri-miR-9-1 possessed a unique Drosha cleavage attributable to its flexible and distorted stem structure. After cleavage, pri-miR-9-1 was 
described as the only paralog able to generate an alternative miR-9 with a shifted seed sequence which showed a potential role in low-grade glioma progression.

Both genetic and epigenetic alterations in miRNA processing proteins can affect miRNA biogenesis and expression. For example, germline and somatic mutations in DROSHA, DGCR8, DICER1, and XPO5 genes have been identified in several cancers, including Wilms tumors [54,55], pleuro-pulmonary blastoma [56], non-epithelial ovarian cancer [57], endometrial, colon, and gastric tumors [58]. Since some of the processing proteins involved in miRNA biogenesis are also implicated in the generation of miRNA variants, the presence of alterations in these genes could represent another mechanism responsible for the isomiRs generation and different expression levels in several diseases, including cancer. Interestingly, in a recent study, Galka-Marciniak et al. [59] analyzed cancer somatic mutations in miRNA biogenesis genes and suggested that DICER1 hotspot mutations could impact the expression levels of some isomiRs.

\subsection{Exoribonucleases and Nucleotidyl Transferases}

In Drosophila melanogaster, the $3^{\prime}$-to-5 $5^{\prime}$ Nibbler exoribonuclease was able to induce $3^{\prime}$ end trimming in more than $25 \%$ of miRNAs of Drosophila, after AGO1 loading. Trimming of miRNA $3^{\prime}$ ends may occur as a final step in RISC assembly and is likely required to enhance target mRNA repression. Nibbler depletion caused the formation of miRNAs intermediates longer than 22 nucleotides. On a phenotypic level, this led to developmental defects as Nibbler is necessary for normal fly development of $D$. melanogaster, indicating a relevant physiological function [60] and encouraging further explorations in higher organisms.

Nucleotidyl transferases, mainly with uridyl or adenosyltransferase activity, are defined as template-independent polymerases able to add nucleotides at the $3^{\prime}$-terminus of RNAs. The nucleotide additions impact miRNA stability and performance, are conserved in animals, occur at certain loci, and are catalyzed by enzymes involved also in the regulation of other RNAs, suggesting the importance and specificity of their role [61-63]. PAPD4/5, ZCCHC6/11 in humans, TUT1, MTPAP, and PAPOLG are the most relevant nucleotidyl transferases described in isomiRs' biogenesis [61,64-66].

\subsection{Editing of RNA and SNPS}

Adenosine-to-inosine (A-to-I) is the most frequent (20\%) modification in the pre-miR sequence. It is mediated by the adenosine deaminases ADARs, principally ADAR1/2 [67,68] A-to-I change can occur in the processing of pri-miRNA and pre-miRNA; if within the seed sequence, given the identification of I as G, RNA editing can affect the role of the modified molecules, resulting for example in the regulation of new target genes $[69,70]$.

Single nucleotide Polymorphisms (SNPs) occur at a $1 \%$ frequency in the human genome and are involved in determining the inter-individual diversity and susceptibility to diseases. SNPs in miRNAs have been associated with defects in miRNAs maturation as well as alterations in miRNA:mRNA interactions in cancer.

For example, the alteration in the biogenesis of the tumor suppressor miR16-1 and its association with the increased risk of familial chronic lymphocytic leukemia was reported by Calin et al. [71] and attributed to mutations on the pri-miR-15a/16-1.

Similarly, the SNP rs2910164 in the pre-miRNA of miR-146a has been linked to the risk of developing cervical cancer [72], while an SNP in the pri-miRNA of miR-128b has been associated with acute lymphocytic leukemia [73].

Several databases (e.g., PolymiRTS, miRNASNP) listing genetic variants in miRNAs' seed regions are now available [74,75], and the effects of some variants have been demonstrated in several pathological conditions [76-79]. 


\section{Significance of isomiRs' Functions}

The aforementioned alterations of miRNAs molecules that lead to isomiRs' generation are suggestive of modifications of their functional capability. Overall, isomiRs activity can be correlated to miRNAs' affected stability and/or target selection and seems to play a role either in supporting [46] or competing [80] with their canonical counterparts. Regarding targeting efficiency, most isomiRs show $3^{\prime}$ variations [28], leaving the $5^{\prime}$ end and the seed region unmodified, with subsequent proper target detection. However, it has been described that the 3 -terminus plays a role to reinforce and maintain stability and specificity during miRNA-MRE interaction. This has been demonstrated especially in presence of mismatches within the seed region [81-83], indicating also that $3^{\prime}$ modifications could have an impact on functions of such miRNA isoforms. On the other hand, variations (additions or deletions) at the level of the $5^{\prime}$ end may cause a seed shifting with consequent functional effects [84]. This can generate the gain or loss of functions in terms of target recognition [85].

In the miRISC, microRNAs guide AGO proteins at the sites of target mRNA $3^{\prime}$ UTR, thus inducing repression of translation or mRNA degradation, depending on the seed region complementarity $[86,87]$. Four paralogs of structurally similar AGO proteins (AGO12-3-4) are expressed in H. sapiens. AGO2 was thought to be the only AGO member with RNA slicer activity [88], however, more recently, the same function was ascribed, under particular conditions, to AGO 3 [89]. Many human miRNAs may associate with all AGOs, although several of them are preferably loaded into specific AGO proteins [86]. Several studies highlighted the interaction between isomiRs and AGO proteins, further indicating their functional role $[27,90]$. Deep-sequencing analysis revealed that some miRNA modifications appear to determine the preference to a different AGO protein loading [91], indicating that isomiRs might affect miRISC function.

\section{1. isomiRs Detection and Quantification}

Several methods can be used for the detection and quantification of isomiRs expression; these primarily include qRT-PCR and NGS approaches.

Poly(A) and stem-loop qRT-PCR are the most common techniques for the analysis of small RNAs due to their high level of specificity and the relatively low impact in terms of experimental times and costs [92]. However, the main limitations are represented by the need to know the sequence, with the consequent impossibility of discovering new molecules, as well as the limited accuracy in the discrimination of sequences that differ by only one/few nucleotides, especially if poorly represented in the sample, as often occurs for miRNA isoforms $[93,94]$.

Alternatively, other PCR-based methods for the analysis of isomiRs expression, include, Dumbbell-PCR [95], two-tailed RT-qPCR [96] as well as Multiplex Single Base Primer Extension Assay [97].

To date, NGS represents the methodology of choice for the detection and quantification of miRNAs and miRNAs variants, particularly for the discovery of new isoforms.

The most important limitation of using this technique is the lack of standardized data analysis protocols and normalization methods, which are essential for obtaining high-quality and reproducible results [47].

Overall, several methods, mainly based on sequence complementarity to precursor, location, and pattern of modified nucleotides or pre-defined isomiRs as well as machine learning approaches were used, depending on research interests or contexts, to explore isomiRs expression patterns $[47,98]$. NGS offers a great opportunity to specifically and sensitively detect isomiRs. However, the analysis of isomiRs remains a challenge, due to the limited number of specific tools available to analyze their expression levels in sequencing experiments and the lack of comparison among them [47] as well as the possible overestimation of isomiRs detected [99]. 


\subsection{Resources and Tools for isomiRs' Analysis}

In 2016, Zhang et al. [100] produced a database listing 308,919 isomiRs from 4706 mature miRNAs (accessible at https:/ / mcg.ustc.edu.cn/bsc/isomir/, accessed on 20 June 2021). Bhattacharya et al. [74] created the PolymiRTS database, with the aim of describing the polymorphisms in microRNAs and their target sites (https://compbio.uthsc.edu/ miRSNP/, accessed on 20 June 2021). miRNASNP-v3 is another database for SNPs in miRNAs and target sites (http:/ / bioinfo.life.hust.edu.cn/miRNASNP/, accessed on 20 June 2021) [101]. Very recently, the Tumor Isomir Encyclopedia (TIE, https:/ /isomir.ccr. cancer.gov /, accessed on 20 June 2021) database was created [102], to query and compare isomiR expression across more than 11,000 tumor samples from The Cancer Genome Atlas (TCGA). Several resources for the analysis of isomiRs can be further accessed at https://tools4mirs.org/software/isomirs_identification/ (accessed on 20 June 2021).

\section{6. isomiRs in Cancer}

IsomiRs can differ from miRNAs in abundance, stability, and role, as they can be functionally redundant or discrepant compared to their canonical counterparts.

It has been proven that isomiRs are constitutively generated, but, while some isoforms are ubiquitous in expression, others exhibit tissue-specific expression and abundance [103]. Thus, the study of isomiRs in cancer could provide further insights into the miRNA's biology and their implication in oncogenesis.

Increasing evidence suggests that isomiRs likely play a role in the pathogenesis and progression of different cancer types and could also contribute to cancer molecular heterogeneity. A further element of interest is the promising use of isomiRs as cancer diagnostic and prognostic biomarkers; for example, Wang et al. [98] demonstrated the capability of a panel of fifty $5^{\prime}$ end isomiRs to effectively classify more than thirty different tumor types. Moreover, isomiRs expression was proven to be superior compared to miRNAs expression in the classification of these different cancer types [103]. Similarly, Lan et al. [104] showed that breast cancer subtypes classification, based on isomiRs expression, was more effective than gene expression profiles.

In the next sections, the state of research on isomiRs in different cancer types will be discussed. The studies discussed herein, with particular focus on isomiRs identified as unique (tissue-specific) or, in some cases, shared among diverse tumors, their expression level and role, are summarized in Table 1.

Table 1. IsomiR identified in different cancer types.

\begin{tabular}{|c|c|c|c|}
\hline IsomiR(s) & Cancer Type & Expression Level/Described Role & Reference \\
\hline Panel of 71 isomiRs & $\begin{array}{l}\text { Breast } \\
\text { Cancer }\end{array}$ & $\begin{array}{c}\text { Differentially expressed in tumor and } \\
\text { normal breast tissues }\end{array}$ & [105] \\
\hline $\begin{array}{l}\text { Isoforms of TJU CMC MD2.ID00121, } \\
\text { miR-125a and } m i R-183-5 p\end{array}$ & $\begin{array}{l}\text { Breast } \\
\text { Cancer }\end{array}$ & $\begin{array}{l}\text { Differentially expressed with regard to BC } \\
\text { patient's race }\end{array}$ & [106] \\
\hline $\begin{array}{l}\text { Isoforms of mir-21-5p, mir-182-5p, } \\
\text { mir-183-5p }\end{array}$ & \multirow{3}{*}{$\begin{array}{l}\text { Breast } \\
\text { Cancer }\end{array}$} & $\begin{array}{l}\text { Up-regulated in TNBC compared to } \\
\text { normal samples }\end{array}$ & \multirow{3}{*}{ [107] } \\
\hline Isoforms of $m i R-10 b$ and $m i R-99 a$ & & $\begin{array}{c}\text { Down-regulated in TNBC compared to } \\
\text { normal samples }\end{array}$ & \\
\hline $\begin{array}{l}\text { Isoforms of } m i R-200 c, \text { miR-21, miR-17/92 } \\
\text { cluster and } m i R-183 / 96 / 182 \text { cluster }\end{array}$ & & $\begin{array}{c}\text { Associated with race disparities in } \\
\text { Caucasian and African-American TNBC } \\
\text { patients }\end{array}$ & \\
\hline $5^{\prime}$ isomiR-140-3p & $\begin{array}{l}\text { Breast } \\
\text { Cancer }\end{array}$ & $\begin{array}{l}\text { Tumor suppressor role via regulation of } \\
\text { cell viability, cell migration, and cell cycle }\end{array}$ & [108] \\
\hline
\end{tabular}


Table 1. Cont.

\begin{tabular}{|c|c|c|c|}
\hline IsomiR(s) & Cancer Type & Expression Level/Described Role & Reference \\
\hline $5^{\prime}$ isomiR-140-3p & $\begin{array}{l}\text { Breast } \\
\text { Cancer }\end{array}$ & $\begin{array}{c}\text { Tumor suppressor role, involved in TNBC } \\
\text { development }\end{array}$ & [109] \\
\hline Variants of $m i R-200 b-3 p$ and $m i R-200 b-5 p$ & $\begin{array}{l}\text { Breast } \\
\text { Cancer }\end{array}$ & $\begin{array}{l}\text { Observed following ectopic expression of } \\
\text { pri-miR-200b in breast cancer cell lines }\end{array}$ & [110] \\
\hline Panel of 20 isomiRs & $\begin{array}{l}\text { Breast } \\
\text { Cancer }\end{array}$ & Able to distinguish $\mathrm{BC}$ subtypes & [104] \\
\hline $3^{\prime}$ isomiR of $m i R-21-5 p$ ( $3^{\prime}$ addition $\left.C\right)$ & $\begin{array}{l}\text { Breast } \\
\text { Cancer }\end{array}$ & $\begin{array}{l}\text { Over-expressed in serum of BC patients } \\
\text { compared to controls }\end{array}$ & [111] \\
\hline 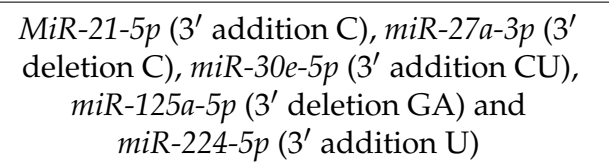 & \multirow[b]{2}{*}{ Colorectal Cancer } & $\begin{array}{l}\text { Higher expression levels than their } \\
\text { canonical counterparts }\end{array}$ & \multirow[b]{2}{*}{ [47] } \\
\hline $\begin{array}{c}\text { Panel of } 58 \text { isomiRs (including miR-135b-5p, } \\
-182-5 p,-183-5 p,-192-5 p,-200 b-3 p \\
-96-5 p,-200 a-3 p,-200 c-3 p, \text { and }-429 \text { and, } \\
\text { overall, miR-17-92, miR-200, and miR-183 } \\
\text { families.) }\end{array}$ & & $\begin{array}{l}\text { Up-regulated in CRC and advanced } \\
\text { adenoma compared to normal tissues }\end{array}$ & \\
\hline Isoforms of mir- $26 a-5 p$ & Colorectal Cancer & $\begin{array}{l}\text { Differentially expressed between MSI } \\
\text { positive and negative tumors }\end{array}$ & [112] \\
\hline MiR-451a.1 & Melanoma & $\begin{array}{l}\text { Tumor suppressive role by inhibition of } \\
\text { melanoma progression }\end{array}$ & [113] \\
\hline $\begin{array}{l}\text { Panel of } 17 \text { isomiRs (including miR-200, } \\
m i R-30 \text {, and } m i R-10 \text { families) }\end{array}$ & \multirow[b]{2}{*}{ Melanoma } & $\begin{array}{l}\text { Higher expression levels than their } \\
\text { canonical counterparts }\end{array}$ & \multirow[b]{2}{*}{ [114] } \\
\hline MiR-125a-5p |0|-2 & & $\begin{array}{l}\text { Higher expression levels than the canonical } \\
\text { miRNA and differentially expressed in } \\
\text { multiple melanomas in the same patient }\end{array}$ & \\
\hline $\operatorname{MiR}-21-5 p|-1| 0$ and miR-29a-3p | -1 | 1 & \multirow{2}{*}{$\begin{array}{l}\text { Uveal } \\
\text { Melanoma }\end{array}$} & $\begin{array}{l}\text { High expression levels associated to } \\
\text { metastasis }\end{array}$ & \multirow{2}{*}{ [115] } \\
\hline MiR-99a-3p | $1 \mid 1$ and let-7c-5p $|-1| 1$ & & $\begin{array}{l}\text { Low expression levels associated to } \\
\text { metastasis }\end{array}$ & \\
\hline IsomiRs of $m i R-21, m i R-204$ and $m i R-375$ & $\begin{array}{l}\text { Prostate } \\
\text { Cancer }\end{array}$ & Putative circulating diagnostic biomarkers & [116] \\
\hline IsomiRs of $m i R-9$ and $m i R-219$ & Glioma & Putative biomarkers in low-grade tumors & [103] \\
\hline MiR-210-3p and related isomiRs & Glioblastoma cell lines & Hypoxia-induced & {$[117]$} \\
\hline IsomiR-27b- 1 and isomiR-27b-2 & AML-12 cells & $\begin{array}{l}\text { Regulation of metabolism-related proteins } \\
\text { expression }\end{array}$ & [118] \\
\hline Isoform of $m i R-574-3 p$ and $m i R-205-5 p$ & Esophageal Carcinoma & Diagnostic biomarkers & [119] \\
\hline MiR-139-5p -1। -1 & $\begin{array}{l}\text { Hepatocellular } \\
\text { Carcinoma }\end{array}$ & Tumor suppressor role by targeting IGF1R & [120] \\
\hline Isoforms of $m i R-146 b-5 p$ and $m i R-146 b-3 p$ & $\begin{array}{l}\text { Thyroid } \\
\text { Carcinoma }\end{array}$ & $\begin{array}{l}\text { Up-regulated in tumors compared to } \\
\text { normal samples }\end{array}$ & [121] \\
\hline IsomiRs of $m i R-196 a$ & $\begin{array}{l}\text { Laryngeal } \\
\text { Cancer }\end{array}$ & Dysregulation in tumor and normal tissues & [122] \\
\hline
\end{tabular}




\subsection{Breast Cancer}

IsomiRs in breast cancer (BC) were studied for the first time by Chang et al. [123] who used NGS data from the NCBI Sequence Read Archive (SRA) to perform differential expression analysis of miRNAs and isomiRs in tumor and adjacent breast normal tissues. In this study, high frequency of position shift was observed at the $3^{\prime}$ end of miRNAs (accounting for about $40 \%$ of all miRNAs reads) and more than $12 \%$ of miRNAs reads showed $3^{\prime}$ end nucleotide modifications in samples; however, no significant differences in isomiRs position shifts and $3^{\prime}$ end modifications between tumor and normal tissue were observed.

Similarly, by using NGS data from The Cancer Genome Atlas (TCGA), Wu et al. [124] performed a comprehensive analysis of miRNAs and isomiRs expression in $683 \mathrm{BC}$ and 87 normal tissues. Although one or more expressed isomiRs were detected for each miRNA locus, none of the isomiRs identified showed variations in the seed sequence at the $5^{\prime}$-end position, which is responsible for the interaction between microRNA and target mRNAs. Thus, the authors suggested a possible functional redundancy, due to the shared target genes between isomiRs and their canonical counterparts, with a consequent contribution in regulating the same pathways. Moreover, no statistically significant differences in isomiR expression profiles emerged between $B C$ and normal tissues.

Starting from miR-seq datasets from TCGA, Zhang et al. [105] developed a bioinformatics approach to characterize and compare the isomiR pattern in normal and breast tumor tissues. Interestingly, a total of 71 isomiRs, most of which arising from the same miRNA locus, showed significant differential expression in normal compared to cancer tissues. Functional annotation and pathway-based analysis of the putative isomiRs targets revealed enrichment for genes involved in well-known cancer-related pathways, such as MAPK signaling and focal adhesion.

A bioinformatics pipeline for the analysis of small RNAs, specifically aimed at distinguishing canonical miRNAs and their variants, was also developed by Muller et al. [125], and used for the analysis of primary normal and triple-negative BC (TNBC) cells. By using this tool, the authors identified more than 1000 isomiRs: the majority of them were "templated isomiRs", most probably deriving from imprecise enzymatic cleavage by Drosha or Dicer leading to variants that perfectly matched the pre-miRNA sequence. IsomiRs that originate from the addition of nucleotides, particularly $3^{\prime}$ end adenylation and uridylation, were also observed both in normal and cancer cells. Interestingly, for 11 miRNAs, including $m i R-148 b-3 p, m i R-152-3 p$, and $m i R-23 b-3 p$, the authors observed that the canonical form appeared poorly or not expressed. On the contrary, the $3^{\prime}$ end non-templated isoform resulted in highly expressed, representing the predominant variant. Overall, results from this study highlighted the importance of improving the methodologies and bioinformatics pipelines for the analysis of miRNAs and their variants, thus analyzing not only miRNAs but also isomiRs expression.

Telonis et al. [106] examined the isomiRs expression profiles by using BC datasets from TCGA. They described not only that isomiRs expression patterns could better distinguish tumor from normal breast tissue than miRNAs patterns, but also that isomiRs were able to discriminate and characterize, at the molecular level, luminal A and luminal B subtypes compared to transcriptome expression profiles. Differential expression of several isomiRs, such as variants from TJU CMC MD2.ID00121 (a novel human-specific miRNA locus), $m i R-125 a$ and $m i R-183-5 p$, was also correlated to patients' ethnicity/race; for example, a statistically significant over-expression of different variants of $m i R-183-5 p$ was observed in triple-negative BC (TNBC) cases from Caucasian patients, but not from African-Americans. Furthermore, three different isoforms of this miRNA demonstrated a different impact on transcriptome profile in MDA-MB-231 BC cells.

A study on the expression pattern and interaction between coding and non-coding RNAs in normal and TNBC patients, again in Caucasian vs African-American women, was also performed by Telonis et al. [107], in order to analyze the regulatory effect of non-coding RNAs on transcriptome profile and to shed light on race-specific molecular differences. 
By adding evidence to their previous study [106], the authors identified differentially expressed isomiRs in normal and tumor tissues: in particular, numerous variants of mir-21$5 p$, mir-182-5p and mir-183-5p were found to be up-regulated, while several isoforms of $m i R-10 b$ and $m i R-99 a$ (both $3 p$ and $5 p$ ) were found down-regulated in TNBC compared to normal samples. Furthermore, isomiRs, including variants arising from miR-200c, miR-21, the $m i R-17 / 92$ and the $m i R-183 / 96 / 182$ clusters, were associated with race-related disparities in terms of metastases-correlated pathways, since a co-expression of these isomiRs and genes belonging to the Wnt signaling pathway was observed almost exclusively in AfricanAmerican TNBC patients. Of note, the canonical form of some isomiRs here identified (e.g., $m i R-21-5 p, m i R-200$ and $m i R-10$ families and the miR-183/96/182 cluster) included miRNAs known to be altered in $B C$.

TNBC tumors were also analyzed by Guo et al. [126], who performed small RNA profiling in 26 TNBC cell lines and compared the expression levels of non-coding RNAs among the four intrinsic TNBC subtypes [basal-like (BL1, BL2), mesenchymal (M), and luminal androgen receptor (LAR)]. They identified several differentially expressed small RNAs (including isomiRs) among the different TNBC subtypes, none of which, however, was unique to each TNBC subtype compared to all other subgroups.

Salem et al. [108] reported high expression levels of shifted $5^{\prime}$ end isoform of miR-140$3 p$, a potential tumor suppressor miRNA previously associated with stemness regulation in $\mathrm{BC}$, both in BC cell lines and tumors. Functional characterization revealed that overexpression of $5^{\prime}$ isomiR-140-3p, but not of miR-140-3p, led to decreased cell viability and migration in $\mathrm{BC}$ cell lines, and induced cell cycle arrest. Due to the $5^{\prime}$ end alteration and the resulting shift of the seed sequence, a different spectrum of target genes was expected. Indeed, genes involved in cell viability, migratory potential, and cell cycle regulation (COL4A1, ITGA6, and MARCKSL1), emerged as three novel specific target genes of the $5^{\prime}$ isomiR-140-3p. Overall, the authors suggested a functional synergy, not a functional redundancy, between $5^{\prime}$ isomiR-140-3p and its canonical miRNA, highlighting that the tumor suppressor role of the above-reported two small RNAs may be regulated by different molecular mechanisms.

In a cell line model of early-stage TNBC, according to Salem et al. [108], Bhardwaj et al. [109] identified the $5^{\prime}$ isomiR of miR-140-3p (miR-140-3p-1) and the new targets HMGCoA reductase (HMGCR) and HMG-CoA synthase 1(HMGCS1), two key genes involved in the cholesterol biosynthesis during the multi-step tumorigenic process, as central regulators of TNBC development. Decreased expression of both isomiR and canonical miRNA during cancer progression (from non-cancer parental cell line to invasive cancer) was observed; indeed, miR-140-3p-1 acted as a tumor suppressor, with loss of miR-140-3p-1 promoting upregulation of HMGCR and HMGCS1.

Lan et al. [104] explored for the first time the potential role of isomiRs as biomarkers for the identification of BC subtypes. By using novel bioinformatics and machine learning methods, they demonstrated the efficacy of isomiRs in distinguishing different $\mathrm{BC}$ subtypes, also improving the knowledge of the molecular mechanisms underlying $\mathrm{BC}$ heterogeneity. Twenty isomiRs were identified as key biomarkers for BC subtype classification. Pathway-based analysis of the predicted target mRNAs revealed five pathways that were significantly affected by isomiRs and known to be involved in BC, notably that of p53, MAPK and Estrogen signaling.

To deepen the relationship between altered miRNAs expression and epithelial-tomesenchymal transition (EMT) in BC, Rhodes et al. [110] analyzed and demonstrated the suppressive effect of $m i R-200 b-3 p$ and $m i R-200 b-5 p$ on EMT in TNBC cell lines. Interestingly, they observed that ectopic expression of pri-miR-200b led to the formation of $m i R-200 b-3 p$ and miR-200b-5p as well as multiple isoforms of both miRNAs, characterized, in particular, by heterogeneity at $3^{\prime}$ position. However, the possible role of these variants in the context of EMT has not been further investigated.

Finally, Koi et al. [111] observed higher expression levels of a specific $3^{\prime}$ isomiR of miR21-5p, together with miR-23a-3p and tRF-Lys (TTT), in serum from BC patients compared to healthy controls, also demonstrating the high accuracy of a model combining these 3 small 
RNAs as a putatively useful diagnostic tool for the detection of early-stage BCs. MiR-21-5p is a known oncogenic miRNA, involved in cancer proliferation and invasion. Of note, altered expression levels of the same $3^{\prime}$ isomiR of $m i R-21-5 p$ identified in this study ( $3^{\prime}$ addition C) were also detected in tissues from colon cancer patients [47], suggesting that this isomiR could be involved in the pathogenesis of different types of tumors.

\subsection{Other Common Tumors: Colorectal Cancer, Melanoma, Prostate Cancer}

Despite the limited number of studies, several proofs indicate that isomiRs generation and their higher expression levels compared to the canonical forms, represent a widespread phenomenon in common tumors, including colorectal cancer, melanoma, and prostate cancer.

\subsubsection{Colorectal Cancer}

Wu et al. [47] developed a sequence-oriented isomiRs annotation (CASMIR) method to specifically analyze isomiRs expression profiles from small-RNA sequencing data, which was tested in colorectal cancers (CRCs), advanced adenoma, and normal samples. IsomiRs were identified as the most abundant small RNAs in CRC samples, accounting for about $70 \%$ of total miRNA reads. Among them, the expression levels of isomiRs of $m i R-21-5 p\left(3^{\prime}\right.$ addition $\mathrm{C}$ ), $m i R-27 a-3 p$ ( $3^{\prime}$ deletion $\mathrm{C}$ ), miR-30e-5p ( $3^{\prime}$ addition $\mathrm{CU}$ ), miR-125a-5p ( $3^{\prime}$ deletion GA) and $m i R-224-5 p$ ( $3^{\prime}$ addition $\mathrm{U}$ ) were found 7 to 18-fold higher than their respective canonical counterparts. Of note, for $m i R-21-5 p$, a widely studied miRNA upregulated in $\mathrm{CRC}$, the greatest abundance of $3^{\prime}$ addition $C$ form suggested a more discriminating role than the canonical form. Fifty-eight isomiRs, including isoforms of miR-135b-5p, -182-5p, $-183-5 p,-192-5 p,-200 b-3 p,-96-5 p,-200 a-3 p,-200 c-3 p$, and -429 , were also found up-regulated in both CRCs and advanced adenoma compared to normal tissues. Overall, the over-expressed isomiRs identified in this study belong to miRNAs families known to be involved in oncogeneses, such as miR-17-92, miR-200, and miR-183 families.

Mjelle et al. [112] identified a large fraction of differentially expressed miRNAs and isomiRs in colon cancer compared to normal samples as well as in microsatellite instability (MSI) positive and negative tumors. Interestingly, they observed that about $50 \%$ of detected miRNAs showed higher variants' expression compared to their canonical forms; overall, 2451 isomiRs, arising from 343 unique miRNAs, were found differentially expressed in tumor and normal samples. Among MSI-positive and negative tumors, $m i R-26 a-5 p$ isomiRs appeared differentially expressed in 48 patients analyzed by sequencing in this study and in TCGA datasets as well.

\subsubsection{Melanoma}

Throughout the study of miRNA expression profiling in melanoma, Kozubek et al. [127] described the presence of widespread non-coding small RNAs, including isomiRs, highlighting the complexity of melanoma transcriptome and miRNome landscape. Among the different miRNA isoforms, miR-451a.1, arising from $m i R-144 / 451 a$ cluster, emerged as the most abundant isomiR of $m i R-451 a$.

The same was extensively studied by Babapoor et al. [113], which demonstrated its association with amelanotic phenotype and tumor-suppressive effects, by inhibition of melanoma invasion/progression. MiR-451a.1 expression was increased in normal skin, with a progressive decrease in melanoma and dysplastic nevi compared to common nevi. After ectopic expression of $m i R-144 / 451 a$ in melanoma cell lines, higher levels of mature miR-451a.1 with respect to $m i R 451 a$ or $m i R-144$, and significant reduction of cell migration, as well as inhibition of invasion, were observed.

Through small-RNome analysis of single and multiple primary melanomas (PMs), Dika et al. [114] identified a set of 17 isomiRs, mainly belonging to miRNA families involved in tumorigenesis, including $m i R-200, m i R-30$, and $m i R-10$ families, that showed higher expression than their canonical forms. In particular, the miR-125a-5p | $0 \mid-2$ isoform was 10-fold more abundant than the canonical counterpart and showed differential expression 
levels in the first tumor with respect to the second one in patients with multiple PMs. Target prediction analysis revealed functional modification of the miR-125a-5p $|0|-2$ isoform and target gene pattern change, leading to the inability of this isomiR to target key genes involved in cell adhesion and migration (Ephrin receptors, Netrin 1) or intracellular signaling (PIK3C2B).

Londin et al. [115] performed small RNA-sequencing in 80 primary uveal melanomas, the subtype arising from melanocytes of the uveal tract, and identified a complex regulatory network involving several small RNAs, including isomiRs. The authors observed that the majority of the identified isomiRs derived from best-studied miRNA loci, such as $m i R-21-5 p, m i R-183-5 p, m i R-143-3 p$. Increased or decreased expression levels of isomiRs from multiple miRNA loci, some of which previously correlated to pathways involved in tumor development and melanoma proliferation, were also associated with molecular phenotypes, disease progression, and patient survival: for example, increased levels of miR-21-5p $|-1| 0$ and miR-29a-3p $|-1| 1$ and decreased levels of miR-99a-3p $|1| 1$ and let-7c-5p |-1|1 were observed in patients with metastases.

\subsubsection{Prostate Cancer}

Magee et al. [128] studied isomiRs and tRNA-derived fragments (tRFs) in a large cohort of prostate cancer (PC) samples from the TCGA dataset. Numerous isomiRs were identified, many of which arose from few miRNA precursors, including miR-143-3p, miR182-5p, miR-21-5p, miR183-5p, miR-10a-5p, and let-7a-5p. Like that previously reported in BC [80], they found different isomiRs expression levels related to patients' ethnicity.

In order to evaluate the potential role of non-coding RNAs as biomarkers of radiation response in PC, Leung et al. [129] explored the possible impact of radiation on miRNA levels, arm selection preference, and isomiRs in a model of radiation-treated PC 3 cells. Regarding isomiRs expression, the authors observed altered $3^{\prime}$ modification of miRNAs after radiation exposure. A gradual increase in the proportion of dinucleotide modifications at the end of the miRNA reads was also observed in PC3 cells after radiation treatment.

Circulating miRNAs and isomiRs, detectable in biofluids such as serum or urine, are emerging as very promising non-invasive biomarkers for disease states. Koppers-Lalic et al. [116] investigated the expression pattern of miRNAs in urine extracellular vesicles (EVs) of PC patients compared to healthy controls. Interestingly, significant differential expression was detected for isomiRs of $m i R-21, m i R-204$, and $m i R-375$. A model to evaluate the diagnostic performance of these 3 isomiRs also demonstrated a higher AUC (area under the curve) value than prostate-specific antigen (PSA), highlighting the promising potential of this panel of 3 isomiRs as a diagnostic tool in PC.

\subsection{Other Cancer Types}

A limited number of papers have been published about isomiRs detection, frequency, and function in other, less common, cancer types. In the present section, a summary of the literature available on the role of isomiRs in several cancers and cancer cell lines including brain tumors, hematological malignancies, gastrointestinal (GI) tract cancers, thyroid carcinoma, and laryngeal cancer is provided.

IsomiRs from $m i R-9$ and $m i R-219$, two microRNAs involved in neuronal development and differentiation, were found specifically expressed in low-grade glioma, suggesting a potential role as biomarkers in this type of tumor [103].

MiR-210-3p and related isomiRs emerged as high hypoxia-inducible small RNAs in glioblastoma cell lines. The authors showed that several additional isomiRs, mainly differing from the canonical forms for a few nucleotides mostly at the $3^{\prime}$ end, also displayed differential expression profiles under hypoxia [117].

Kuchenbauer et al. [50] described isomiRs in a murine leukemia progression model. The authors observed that almost all detected miRNAs presented as one or more variants, identifying a total of 3390 isomiRs from 225 different miRNAs. Although the potential role of these variants in post-transcriptional regulation was not investigated, the authors 
highlighted that the miRNA transcriptome landscape was more complex than previously supposed.

Guo et al. [130] hypothesized that small RNA alteration levels could be implicated in the transformation of myelodysplastic syndromes (MDS) to Acute Myeloid Leukemia (AML). Besides five miRNAs, including three members of the miR-181 family, they identified two differentially expressed isomiRs (miR-10a-5p+1 and hsa-miR-92a-3p+2) in MDS patients who never progressed to AML compared with MDS patients who progressed to AML; however, the difference of the two isomiRs' expression was not statistically significant after adjustment for blast percentage and age.

The expression and function of isomiRs from the miR-27 family in cancer were analyzed by Ma et al. [118]. Through the use of miRNAs and isomiRs transfection into AML cells (AML-12 cells), they demonstrated the suppressive role of canonical miR-27b on the expression of metabolism-related proteins, including PEPCK, G6Pase, FAS, and CPT1A. However, this inhibitory effect was considerably decreased when AML-12 cells were transfected with isomiR-27b-1 or isomiR-27b-2, suggesting the possible regulatory function of such isomiRs in biological processes, not necessarily redundant with respect to their canonical form.

By RNA-sequencing analysis of T-cell acute lymphoblastic leukemia (T-ALL) patients, Wallaert et al. [131] identified 2139 isomiRs arising from 481 different miRNAs: for 106 of them, the canonical form was not detected, suggesting that several miRNAs could often be more represented by alternative forms rather than the canonical form. An association between the expression levels of specific miRNAs and the number of isomiRs arising from them was also observed; an example is represented by $m i R-181 a-5 p$, which showed the highest average expression in T-ALL, as well as 39 different isoforms, detected. Similarly, Dawidowska et al. [132] performed small RNA sequencing of 34 pediatric T-ALL samples, including the characterization of isomiR expression patterns. They observed that the majority of miRNAs (about 70\%) detected were represented by up to 10 isoforms.

The small RNA transcriptional landscape of 30 primary multiple myeloma tumors, including the discovery and characterization of isomiRs, was analyzed by Agnelli et al. [133]. Among the isoforms detected, about $76 \%$ were characterized by shorter or longer mature species without mismatches. In some cases, the expression of the variants was higher than the canonical form or represented up to the whole signal, as was noted for miR-150-3p.

Finally, Loher et al. [134] analyzed isomiR expression profiles in lymphoblastoid cell lines (LCLs) from five different population groups. Several isomiRs, with modifications at the $5^{\prime}, 3^{\prime}$ end, or both, were identified and showed population- and gender-specific expression patterns. Overall, expression levels of 76 isomiRs showed statistically significant population-dependent differences; among them, the authors focused on variants from miR1304-3p (in particular, an isomiR which lacked 2 nucleotides at the $3^{\prime}$-end with respect to the canonical form) and variants from miR-143-3p (in particular, an isomiR characterized by an extra nucleotide at the $3^{\prime}$-end). Isoforms from these two miRNAs were found more abundant in Yoruban Africans (both males and females) and European ancestry (only in females) compared with other populations, respectively.

Regarding GI tract cancers, in order to investigate miRNAs/isomiRs and circular RNAs expression profiles as well as possible interactions among them, Guo et al. [135] analyzed tumor and adjacent-normal samples from patients with esophageal cancer. They observed altered expression levels for several miRNAs and isomiRs. Furthermore, the number of predicted miRNA-circular RNAs interactions was significantly increased when isomiRs were considered for the analysis. Overall, the authors highlighted the potential functional relationship and crosstalk complexity of the different deregulated RNA species in esophageal cancer, particularly related to the expression of isomiRs.

The potential role of circulating miRNAs and isomiRs as non-invasive biomarkers in esophageal cancer was investigated by Ibuki et al. [119] through the analysis of esophageal squamous cell carcinoma (ESCC) samples and matched normal controls. A model including $m i R-30 a-5 p$ and two isomiRs (variants of $m i R-574-3 p$ and $m i R-205-5 p$ ) demonstrated 
high diagnostic performance, with an AUC value of 0.95 and sensitivity and specificity parameters higher than $80 \%$, highlighting the promising potentiality of this three small RNAs panel as a diagnostic tool in ESCC.

Sequencing analysis of small RNAs, including isomiRs, from a gastric tumor and its corresponding normal tissue, was performed by $\mathrm{Li}$ et al. [136]. The authors reported a different $5 p / 3 p$ arm ratio of the same pre-miRNAs in the two tissue types and differential expression preferences in the enrichment of specific isomiRs, with different variants from the same miRNA which preferentially occurred in normal or gastric tissue, respectively (e.g., miR-497 and mir-21). In other cases, differences in the abundance of the same isomiRs (e.g., let-7a) as well as differences in the expression levels of canonical miRNAs, but similar isomiR distribution pattern (e.g., $m i R-30 b$ ) were observed, demonstrating a wide and diverse range of isomiRs distribution in normal and tumor tissue.

The analysis of transcriptome and small RNA profiles of extracellular vesicles (EVs) cargoes from four liver-cancer cell lines revealed a shared background as well as cell line-specific characteristics in terms of both coding and non-coding RNA species [137]. Regarding isomiRs expression, miRNAs variants accounted for about $26-30 \%$ of the total miRNAs reads across all the four cell lines. As expected, $3^{\prime}$ end isomiRs were the predominant category, although internal nucleotide modifications, alone or in combination with $3^{\prime}$ or $5^{\prime}$ end alterations, were also found. Overall, the authors observed a high correlation between the expression of isomiRs and their canonical counterparts, suggesting a possible similar biological role of miRNAs and corresponding isoforms in EVs context. Indeed, isomiRs can be functionally redundant to their canonical miRNAs, as it was reported for miR-139-5p variants, in particular miR-139-5p -1 I-1, for which a synergistic role to suppress tumor development and progression by targeting IGF1R was observed in hepatocellular carcinoma [120].

MicroRNA transcriptome in normal thyroid and papillary thyroid carcinoma (PTC) was analyzed by Swierniak et al. [121]. Several tissue-specific isomiRs, including $5^{\prime}$ end isomiRs with alteration of the seed sequences and consequent differences in the putative target genes recognition, were detected. Six different $5^{\prime}$ end isoforms of miR-146b-5p a highly deregulated miRNA in PTC, were shown. These variants, whose expression was 14-29 times higher in tumor than in control tissue, were characterized by the modification of one nucleotide, leading to the formation of two alternative seed regions whose predicted target genes overlapped for only $13 \%$. Similarly, the passenger strand of the pre-miRNA (miR-146b-3p) produced four $5^{\prime}$ end isoforms, with the generation of isomiRs with 2 different seed regions; in this case, the predicted target genes which were regulated by both seeds accounted for $9.4 \%$.

By contrast, Saiselet et al. [138] did not observe correlations between isomiRs, in terms of isoforms distribution, $5 \mathrm{p}$-to-3p arm expression ratios and non-templated additions, and PTC tumorigenesis or lymph node metastases process.

Parafioriti et al. [139] performed miRNoma profiling in chondrosarcoma tissues and identified several differentially expressed miRNAs and isomiRs in grade II-III compared with grade I samples. Analyzing predicted target genes, particularly for $5^{\prime}$ end isoforms, the authors observed that many of the pathways targeted by these isomiRs were involved in cancer-associated signaling, also suggesting a synergistic role with the canonical counterparts.

Finally, small RNA-sequencing analysis revealed quantitative and qualitative alterations in the expression of isomiRs of miR-196a in laryngeal cancer, with the presence of high levels of isomiRs with complete length in laryngeal cancers, and low levels of mature miR-196a as well as expression of a truncated variant (deletion of 1-2 nucleotides at both ends) in normal laryngeal tissues [122]. 


\section{Discussion and Conclusions}

To date, it is well established that miRNAs can be present in several isoforms that are heterogeneous in length and/or sequence. IsomiRs generation is not a rare event and has been estimated to contribute to half of the miRNome in human cells. The discovery of isomiRs, and their inclusion in miRNome analysis, highlighted the complexity of the small RNA transcriptional landscape in several diseases, including cancer [50].

Recent studies have characterized both the expression and the possible biological function of isomiRs arising from a single miRNA as well as the isomiRs expression patterns within a specific cancer type.

While some isomiRs appear to be tumor-specific, others emerged as ubiquitously expressed in several human cancers and cancer cell lines. For example, high expression levels of isomiRs arising from miRNAs families known to be implicated in human tumorigenesis, particularly mir-21-5p, miR-200, and miR-183 families, were frequently observed and shared among almost all cancer types.

However, isomiRs are a recently identified class of molecules and most studies to date are focused on the type and abundance of isomiRs compared to canonical miRNAs rather than on the differential expression analysis in different tumor types and subtypes, or on the analysis of the biological role of altered classes of isomiRs.

In conclusion, data on different cancer types suggest that isomiRs generation is a widespread phenomenon in tumors. Based on the known and growing importance of miRNAs as promising diagnostic and prognostic markers, and the molecular and clinical heterogeneity of cancers as well, further analyses are required to better characterize the expression patterns of isomiRs and their role in cancer pathogenesis and progression to provide new insights into cancer heterogeneity.

Author Contributions: Conceptualization, V.Z., E.A. and A.T.; writing-original draft preparation, V.Z., C.C. and R.C.; bibliographic information, A.C., J.C., D.V. and M.D.P.; writing-review and editing, F.Z., E.A. and A.T. All authors have read and agreed to the published version of the manuscript.

Funding: This work was in part supported by "DISCAB GRANT 2021" to V.Z. awarded by the Department of Biotechnological and Applied Clinical Sciences, University of L'Aquila.

Institutional Review Board Statement: Not applicable.

Informed Consent Statement: Not applicable.

Data Availability Statement: Not applicable.

Acknowledgments: V.Z. and D.V. are supported by PON-AIM 2014-2020 Research and Innovation funding. J.C. and A.C. are supported by PON 2014-2020 Research and Innovation PhD program. The authors wish to thank Paul A O'Sullivan for his contribution in critically reading the manuscript and English language editing.

Conflicts of Interest: The authors declare no conflict of interest.

\section{References}

1. Lee, R.C.; Feinbaum, R.L.; Ambros, V. The C. elegans heterochronic gene lin-4 encodes small RNAs with antisense complementarity to lin-14. Cell 1993, 75, 843-854. [CrossRef]

2. Reinhart, B.J.; Slack, F.J.; Basson, M.; Pasquinelli, A.E.; Bettinger, J.C.; Rougvie, A.E.; Horvitz, H.R.; Ruvkun, G. The 21-nucleotide let-7 RNA regulates developmental timing in Caenorhabditis elegans. Nature 2000, 403, 901-906. [CrossRef]

3. Hsu, P.W.; Huang, H.D.; Hsu, S.D.; Lin, L.Z.; Tsou, A.P.; Tseng, C.P.; Stadler, P.F.; Washietl, S.; Hofacker, I.L. miRNAMap: Genomic maps of microRNA genes and their target genes in mammalian genomes. Nucleic Acids Res. 2006, 34, D135-D139. [CrossRef]

4. Zhou, S.S.; Jin, J.P.; Wang, J.Q.; Zhang, Z.G.; Freedman, J.H.; Zheng, Y.; Cai, L. miRNAS in cardiovascular diseases: Potential biomarkers, therapeutic targets and challenges. Acta Pharm. Sin. 2018, 39, 1073-1084. [CrossRef] [PubMed]

5. Siasos, G.; Bletsa, E.; Stampouloglou, P.K.; Oikonomou, E.; Tsigkou, V.; Paschou, S.A.; Vlasis, K.; Marinos, G.; Vavuranakis, M.; Stefanadis, C.; et al. MicroRNAs in cardiovascular disease. Hell. J Cardiol. 2020, 61, 165-173. [CrossRef] [PubMed] 
6. Juźwik, C.A.; Drake, S.S.; Zhang, Y.; Paradis-Isler, N.; Sylvester, A.; Amar-Zifkin, A.; Douglas, C.; Morquette, B.; Moore, C.S.; Fournier, A.E. microRNA dysregulation in neurodegenerative diseases: A systematic review. Prog. Neurobiol. 2019, $182,101664$. [CrossRef] [PubMed]

7. Peng, Y.; Croce, C.M. The role of MicroRNAs in human cancer. Signal Transduct. Target. Ther. 2016, 1, 15004. [CrossRef]

8. Svoronos, A.A.; Engelman, D.M.; Slack, F.J. OncomiR or Tumor Suppressor? The Duplicity of MicroRNAs in Cancer. Cancer Res. 2016, 76, 3666-3670. [CrossRef]

9. Condrat, C.E.; Thompson, D.C.; Barbu, M.G.; Bugnar, O.L.; Boboc, A.; Cretoiu, D.; Suciu, N.; Cretoiu, S.M.; Voinea, S.C. miRNAs as Biomarkers in Disease: Latest Findings Regarding Their Role in Diagnosis and Prognosis. Cells 2020, 9, 276. [CrossRef]

10. Valentini, V.; Zelli, V.; Gaggiano, E.; Silvestri, V.; Rizzolo, P.; Bucalo, A.; Calvieri, S.; Grassi, S.; Frascione, P.; Donati, P.; et al. MiRNAs as Potential Prognostic Biomarkers for Metastasis in Thin and Thick Primary Cutaneous Melanomas. Anticancer Res. 2019, 39, 4085-4093. [CrossRef]

11. Arroyo, J.D.; Chevillet, J.R.; Kroh, E.M.; Ruf, I.K.; Pritchard, C.C.; Gibson, D.F.; Mitchell, P.S.; Bennett, C.F.; Pogosova-Agadjanyan, E.L.; Stirewalt, D.L.; et al. Argonaute2 complexes carry a population of circulating microRNAs independent of vesicles in human plasma. Proc. Natl. Acad. Sci. USA 2011, 108, 5003-5008. [CrossRef]

12. Li, L.; Zhu, D.; Huang, L.; Zhang, J.; Bian, Z.; Chen, X.; Liu, Y.; Zhang, C.Y.; Zen, K. Argonaute 2 complexes selectively protect the circulating microRNAs in cell-secreted microvesicles. PLoS ONE 2012, 7, e46957. [CrossRef]

13. Vickers, K.C.; Palmisano, B.T.; Shoucri, B.M.; Shamburek, R.D.; Remaley, A.T. MicroRNAs are transported in plasma and delivered to recipient cells by high-density lipoproteins. Nat. Cell Biol. 2011, 13, 423-433. [CrossRef]

14. Sanz-Rubio, D.; Martin-Burriel, I.; Gil, A.; Cubero, P.; Forner, M.; Khalyfa, A.; Marin, J.M. Stability of Circulating Exosomal miRNAs in Healthy Subjects. Sci. Rep. 2018, 8, 10306. [CrossRef]

15. Takahasi, K.; Iinuma, H.; Wada, K.; Minezaki, S.; Kawamura, S.; Kainuma, M.; Ikeda, Y.; Shibuya, M.; Miura, F.; Sano, K. Usefulness of exosome-encapsulated microRNA-451a as a minimally invasive biomarker for prediction of recurrence and prognosis in pancreatic ductal adenocarcinoma. J. Hepato-Biliary-Pancreat. Sci. 2017, 25, 155-161. [CrossRef] [PubMed]

16. Soeda, N.; Iinuma, H.; Suzuki, Y.; Tsukahara, D.; Midorikawa, H.; Igarashi, Y.; Kumata, Y.; Horikawa, M.; Kiyokawa, T.; Fukagawa, T; et al. Plasma exosome-encapsulated microRNA-21 and microRNA-92a are promising biomarkers for the prediction of peritoneal recurrence in patients with gastric cancer. Oncol. Lett. 2019, 18, 4467-4480. [CrossRef] [PubMed]

17. Sun, Z.; Shi, K.; Yang, S.; Liu, J.; Zhou, Q.; Wang, G.; Song, J.; Li, Z.; Zhang, Z.; Yuan, W. Effect of exosomal miRNA on cancer biology and clinical applications. Mol. Cancer 2018, 17, 1-19. [CrossRef] [PubMed]

18. Tessitore, A.; Cicciarelli, G.; Mastroiaco, V.; Vecchio, F.D.; Capece, D.; Verzella, D.; Fischietti, M.; Vecchiotti, D.; Zazzeroni, F.; Alesse, E. Therapeutic Use of MicroRNAs in Cancer. Anti Cancer Agents Med. Chem. 2016, 16, 7-19. [CrossRef]

19. Forterre, A.; Komuro, H.; Aminova, S.; Harada, M. A Comprehensive Review of Cancer MicroRNA Therapeutic Delivery Strategies. Cancers 2020, 12, 1852. [CrossRef]

20. Zelli, V.; Compagnoni, C.; Cannita, K.; Capelli, R.; Capalbo, C.; Di Vito Nolfi, M.; Alesse, E.; Zazzeroni, F.; Tessitore, A. Applications of Next Generation Sequencing to the Analysis of Familial Breast/Ovarian Cancer. High-Throughput 2020, 9, 1. [CrossRef]

21. Sdassi, N.; Silveri, L.; Laubier, J.; Tilly, G.; Costa, J.; Layani, S.; Vilotte, J.L.; Le Provost, F. Identification and characterization of new miRNAs cloned from normal mouse mammary gland. BMC Genom. 2009, 10, 149. [CrossRef]

22. Reese, T.A.; Xia, J.; Johnson, L.S.; Zhou, X.; Zhang, W.; Virgin, H.W. Identification of novel microRNA-like molecules generated from herpesvirus and host tRNA transcripts. J. Virol. 2010, 84, 10344-10353. [CrossRef]

23. Lee, L.W.; Zhang, S.; Etheridge, A.; Ma, L.; Martin, D.; Galas, D.; Wang, K. Complexity of the microRNA repertoire revealed by next-generation sequencing. RNA 2010, 16, 2170-2180. [CrossRef] [PubMed]

24. Morin, R.D.; O'Connor, M.D.; Griffith, M.; Kuchenbauer, F.; Delaney, A.; Prabhu, A.L.; Zhao, Y.; McDonald, H.; Zeng, T.; Hirst, M.; et al. Application of massively parallel sequencing to microRNA profiling and discovery in human embryonic stem cells. Genome Res. 2008, 18, 610-621. [CrossRef] [PubMed]

25. Neilsen, C.T.; Goodall, G.J.; Bracken, C.P. IsomiRs-The overlooked repertoire in the dynamic microRNAome. Trends Genet. 2012, 28, 544-549. [CrossRef] [PubMed]

26. Tomasello, L.; Distefano, R.; Nigita, G.; Croce, C.M. The MicroRNA Family Gets Wider: The IsomiRs Classification and Role. Front. Cell Dev. Biol. 2021, 9, 668648. [CrossRef] [PubMed]

27. Llorens, F.; Bañez-Coronel, M.; Pantano, L.; del Río, J.A.; Ferrer, I.; Estivill, X.; Martí, E. A highly expressed miR-101 isomiR is a functional silencing small RNA. BMC Genom. 2013, 14, 104. [CrossRef] [PubMed]

28. Tan, G.C.; Chan, E.; Molnar, A.; Sarkar, R.; Alexieva, D.; Isa, I.M.; Robinson, S.; Zhang, S.; Ellis, P.; Langford, C.F.; et al. 5 ' isomiR variation is of functional and evolutionary importance. Nucleic Acids Res. 2014, 42, 9424-9435. [CrossRef]

29. Ibing, S.; Michels, B.E.; Mosdzien, M.; Meyer, H.R.; Feuerbach, L.; Korner, C. On the impact of batch effect correction in TCGA isomiR expression data. NAR Cancer 2021, 3, zcab007. [CrossRef]

30. Gu, S.; Kay, M.A. How do miRNAs mediate translational repression? Silence 2010, 1, 11. [CrossRef]

31. O'Brien, J.; Hayder, H.; Zayed, Y.; Peng, C. Overview of MicroRNA Biogenesis, Mechanisms of Actions, and Circulation. Front. Endocrinol. 2018, 9, 402. [CrossRef]

32. Pillai, R.S.; Bhattacharyya, S.N.; Artus, C.G.; Zoller, T.; Cougot, N.; Basyuk, E.; Bertrand, E.; Filipowicz, W. Inhibition of translational initiation by Let-7 MicroRNA in human cells. Science 2005, 309, 1573-1576. [CrossRef] 
33. Humphreys, D.T.; Westman, B.J.; Martin, D.I.; Preiss, T. MicroRNAs control translation initiation by inhibiting eukaryotic initiation factor 4E/cap and poly(A) tail function. Proc. Natl. Acad. Sci. USA 2005, 102, 16961-16966. [CrossRef] [PubMed]

34. Barman, B.; Bhattacharyya, S.N. mRNA Targeting to Endoplasmic Reticulum Precedes Ago Protein Interaction and MicroRNA (miRNA)-mediated Translation Repression in Mammalian Cells. J. Biol. Chem. 2015, 290, 24650-24656. [CrossRef] [PubMed]

35. Bridge, K.S.; Shah, K.M.; Li, Y.; Foxler, D.E.; Wong, S.C.K.; Miller, D.C.; Davidson, K.M.; Foster, J.G.; Rose, R.; Hodgkinson, M.R.; et al. Argonaute Utilization for miRNA Silencing Is Determined by Phosphorylation-Dependent Recruitment of LIM-DomainContaining Proteins. Cell Rep. 2017, 20, 173-187. [CrossRef] [PubMed]

36. Su, H.; Trombly, M.I.; Chen, J.; Wang, X. Essential and overlapping functions for mammalian Argonautes in microRNA silencing. Genes Dev. 2009, 23, 304-317. [CrossRef] [PubMed]

37. Jo, M.H.; Shin, S.; Jung, S.R.; Kim, E.; Song, J.J.; Hohng, S. Human Argonaute 2 Has Diverse Reaction Pathways on Target RNAs. Mol. Cell 2015, 59, 117-124. [CrossRef]

38. Janas, M.M.; Wang, B.; Harris, A.S.; Aguiar, M.; Shaffer, J.M.; Subrahmanyam, Y.V.; Behlke, M.A.; Wucherpfennig, K.W.; Gygi, S.P.; Gagnon, E.; et al. Alternative RISC assembly: Binding and repression of microRNA-mRNA duplexes by human Ago proteins. RNA 2012, 18, 2041-2055. [CrossRef]

39. Shivdasani, R.A. MicroRNAs: Regulators of gene expression and cell differentiation. Blood 2006, 108, 3646-3653. [CrossRef]

40. Peter, M.E. Targeting of mRNAs by multiple miRNAs: The next step. Oncogene 2010, 29, 2161-2164. [CrossRef]

41. Wu, S.; Huang, S.; Ding, J.; Zhao, Y.; Liang, L.; Liu, T.; Zhan, R.; He, X. Multiple microRNAs modulate p21Cip1/Waf1 expression by directly targeting its $3^{\prime}$ untranslated region. Oncogene 2010, 29, 2302-2308. [CrossRef]

42. Del Vecchio, F.; Gallo, F.; Di Marco, A.; Mastroiaco, V.; Caianiello, P.; Zazzeroni, F.; Alesse, E.; Tessitore, A. Bioinformatics approach to predict target genes for dysregulated microRNAs in hepatocellular carcinoma: Study on a chemically-induced HCC mouse model. BMC Bioinform. 2015, 16, 1-11. [CrossRef]

43. Vlachos, I.S.; Zagganas, K.; Paraskevopoulou, M.D.; Georgakilas, G.; Karagkouni, D.; Vergoulis, T.; Dalamagas, T.; Hatzigeorgiou, A.G. DIANA-miRPath v3.0: Deciphering microRNA function with experimental support. Nucleic Acids Res. 2015, 43, W460-W466. [CrossRef] [PubMed]

44. Vlachos, I.S.; Hatzigeorgiou, A.G. Functional Analysis of miRNAs Using the DIANA Tools Online Suite. Methods Mol. Biol. 2017, 1517, 25-50. [CrossRef] [PubMed]

45. Landgraf, P.; Rusu, M.; Sheridan, R.; Sewer, A.; Iovino, N.; Aravin, A.; Pfeffer, S.; Rice, A.; Kamphorst, A.O.; Landthaler, M. A mammalian microRNA expression atlas based on small RNA library sequencing. Cell 2007, 129, 1401-1414. [CrossRef] [PubMed]

46. Cloonan, N.; Wani, S.; Xu, Q.; Gu, J.; Lea, K.; Heater, S.; Barbacioru, C.; Steptoe, A.L.; Martin, H.C.; Nourbakhsh, E. MicroRNAs and their isomiRs function cooperatively to target common biological pathways. Genome Biol. 2011, 12, R126. [CrossRef] [PubMed]

47. Wu, C.W.; Evans, J.M.; Huang, S.; Mahoney, D.W.; Dukek, B.A.; Taylor, W.R.; Yab, T.C.; Smyrk, T.C.; Jen, J.; Kisiel, J.B.; et al. A Comprehensive Approach to Sequence-oriented IsomiR annotation (CASMIR): Demonstration with IsomiR profiling in colorectal neoplasia. BMC Genom. 2018, 19, 401. [CrossRef]

48. Kim, V.N. MicroRNA biogenesis: Coordinated cropping and dicing. Nat. Rev. Mol. Cell Biol. 2005, 6, 376-385. [CrossRef]

49. Ha, M.; Kim, V.N. Regulation of microRNA biogenesis. Nat. Rev. Mol. Cell Biol. 2014, 15, 509-524. [CrossRef]

50. Kuchenbauer, F.; Morin, R.D.; Argiropoulos, B.; Petriv, O.I.; Griffith, M.; Heuser, M.; Yung, E.; Piper, J.; Delaney, A.; Prabhu, A.L. In-depth characterization of the microRNA transcriptome in a leukemia progression model. Genome Res. 2008, 18, $1787-1797$. [CrossRef]

51. Wu, H.; Ye, C.; Ramirez, D.; Manjunath, N. Alternative processing of primary microRNA transcripts by Drosha generates $5^{\prime}$ end variation of mature microRNA. PLoS ONE 2009, 4, e7566. [CrossRef]

52. Zhou, H.; Arcila, M.L.; Li, Z.; Lee, E.J.; Henzler, C.; Liu, J.; Rana, T.M.; Kosik, K.S. Deep annotation of mouse iso-miR and iso-moR variation. Nucleic Acids Res. 2012, 40, 5864-5875. [CrossRef] [PubMed]

53. Bofill-De Ros, X.; Kasprzak, W.K.; Bhandari, Y.; Fan, L.; Cavanaugh, Q.; Jiang, M.; Dai, L.; Yang, A.; Shao, T.J.; Shapiro, B.A.; et al. Structural Differences between Pri-miRNA Paralogs Promote Alternative Drosha Cleavage and Expand Target Repertoires. Cell Rep. 2019, 26, 447-459.e4. [CrossRef] [PubMed]

54. Rakheja, D.; Chen, K.S.; Liu, Y.; Shukla, A.A.; Schmid, V.; Chang, T.C.; Khokhar, S.; Wickiser, J.E.; Karandikar, N.J.; Malter, J.S.; et al. Somatic mutations in DROSHA and DICER1 impair microRNA biogenesis through distinct mechanisms in Wilms tumors. Nat. Commun. 2014, 5, 4802. [CrossRef] [PubMed]

55. Walz, A.L.; Ooms, A.; Gadd, S.; Gerhard, D.S.; Smith, M.A.; Guidry Auvil, J.M.; Meerzaman, D.; Chen, Q.R.; Hsu, C.H.; Yan, C.; et al. Recurrent DGCR8, DROSHA, and SIX homeodomain mutations in favorable histology Wilms tumors. Cancer Cell 2015, 27, 286-297. [CrossRef] [PubMed]

56. Hill, D.A.; Ivanovich, J.; Priest, J.R.; Gurnett, C.A.; Dehner, L.P.; Desruisseau, D.; Jarzembowski, J.A.; Wikenheiser-Brokamp, K.A.; Suarez, B.K.; Whelan, A.J.; et al. DICER1 mutations in familial pleuropulmonary blastoma. Science 2009, 325, 965. [CrossRef]

57. Heravi-Moussavi, A.; Anglesio, M.S.; Cheng, S.W.; Senz, J.; Yang, W.; Prentice, L.; Fejes, A.P.; Chow, C.; Tone, A.; Kalloger, S.E.; et al. Recurrent somatic DICER1 mutations in nonepithelial ovarian cancers. N. Engl. J. Med. 2012, 366, 234-242. [CrossRef] [PubMed]

58. Melo, S.A.; Moutinho, C.; Ropero, S.; Calin, G.A.; Rossi, S.; Spizzo, R.; Fernandez, A.F.; Davalos, V.; Villanueva, A.; Montoya, G.; et al. A genetic defect in exportin-5 traps precursor microRNAs in the nucleus of cancer cells. Cancer Cell 2010, 18, 303-315. [CrossRef] 
59. Galka-Marciniak, P.; Urbanek-Trzeciak, M.O.; Nawrocka, P.M.; Kozlowski, P. A pan-cancer atlas of somatic mutations in miRNA biogenesis genes. Nucleic Acids Res. 2021, 49, 601-620. [CrossRef]

60. Han, B.W.; Hung, J.H.; Weng, Z.; Zamore, P.D.; Ameres, S.L. The 3'-to-5' exoribonuclease Nibbler shapes the $3^{\prime}$ ends of microRNAs bound to Drosophila Argonaute1. Curr. Biol. 2011, 21, 1878-1887. [CrossRef]

61. Burroughs, A.M.; Ando, Y.; de Hoon, M.J.; Tomaru, Y.; Nishibu, T.; Ukekawa, R.; Funakoshi, T.; Kurokawa, T.; Suzuki, H.; Hayashizaki, Y. A comprehensive survey of $3^{\prime}$ animal miRNA modification events and a possible role for $3^{\prime}$ adenylation in modulating miRNA targeting effectiveness. Genome Res. 2010, 20, 1398-1410. [CrossRef]

62. Berezikov, E.; Robine, N.; Samsonova, A.; Westholm, J.O.; Naqvi, A.; Hung, J.H.; Okamura, K.; Dai, Q.; Bortolamiol-Becet, D.; Martin, R. Deep annotation of Drosophila melanogaster microRNAs yields insights into their processing, modification, and emergence. Genome Res. 2011, 21, 203-215. [CrossRef] [PubMed]

63. Burroughs, A.M.; Ando, Y. Identifying and characterizing functional 3' nucleotide addition in the miRNA pathway. Methods 2019, 152, 23-30. [CrossRef]

64. Jones, M.R.; Quinton, L.J.; Blahna, M.T.; Neilson, J.R.; Fu, S.; Ivanov, A.R.; Wolf, D.A.; Mizgerd, J.P. Zcchc11-dependent uridylation of microRNA directs cytokine expression. Nat. Cell Biol. 2009, 11, 1157-1163. [CrossRef]

65. Katoh, T.; Sakaguchi, Y.; Miyauchi, K.; Suzuki, T.; Kashiwabara, S.; Baba, T.; Suzuki, T. Selective stabilization of mammalian microRNAs by $3^{\prime}$ adenylation mediated by the cytoplasmic poly(A) polymerase GLD-2. Genes Dev. 2009, 23, 433-438. [CrossRef]

66. Wyman, S.K.; Knouf, E.C.; Parkin, R.K.; Fritz, B.R.; Lin, D.W.; Dennis, L.M.; Krouse, M.A.; Webster, P.J.; Tewari, M. Posttranscriptional generation of miRNA variants by multiple nucleotidyl transferases contributes to miRNA transcriptome complexity. Genome Res. 2011, 21, 1450-1461. [CrossRef] [PubMed]

67. Yang, W.; Chendrimada, T.P.; Wang, Q.; Higuchi, M.; Seeburg, P.H.; Shiekhattar, R.; Nishikura, K. Modulation of microRNA processing and expression through RNA editing by ADAR deaminases. Nat. Struct. Mol. Biol. 2006, 13, 13-21. [CrossRef] [PubMed]

68. Li, L.; Song, Y.; Shi, X.; Liu, J.; Xiong, S.; Chen, W.; Fu, Q.; Huang, Z.; Gu, N.; Zhang, R. The landscape of miRNA editing in animals and its impact on miRNA biogenesis and targeting. Genome Res. 2018, 28, 132-143. [CrossRef]

69. Kawahara, Y.; Zinshteyn, B.; Sethupathy, P.; Iizasa, H.; Hatzigeorgiou, A.G.; Nishikura, K. Redirection of silencing targets by adenosine-to-inosine editing of miRNAs. Science 2007, 315, 1137-1140. [CrossRef]

70. Glogovitis, I.; Yahubyan, G.; Würdinger, T.; Koppers-Lalic, D.; Baev, V. isomiRs-Hidden Soldiers in the miRNA Regulatory Army, and How to Find Them? Biomolecules 2020, 11, 41. [CrossRef]

71. Calin, G.A.; Ferracin, M.; Cimmino, A.; Di Leva, G.; Shimizu, M.; Wojcik, S.E.; Iorio, M.V.; Visone, R.; Sever, N.I.; Fabbri, M.; et al. A MicroRNA signature associated with prognosis and progression in chronic lymphocytic leukemia. N. Engl. J. Med. 2005, 353, 1793-1801. [CrossRef] [PubMed]

72. Yue, C.; Wang, M.; Ding, B.; Wang, W.; Fu, S.; Zhou, D.; Zhang, Z.; Han, S. Polymorphism of the pre-miR-146a is associated with risk of cervical cancer in a Chinese population. Gynecol. Oncol. 2011, 122, 33-37. [CrossRef]

73. Kotani, A.; Ha, D.; Schotte, D.; den Boer, M.L.; Armstrong, S.A.; Lodish, H.F. A novel mutation in the miR-128b gene reduces miRNA processing and leads to glucocorticoid resistance of MLL-AF4 acute lymphocytic leukemia cells. Cell Cycle 2010, 9, 1037-1042. [CrossRef] [PubMed]

74. Bhattacharya, A.; Ziebarth, J.D.; Cui, Y. PolymiRTS database 3.0: Linking polymorphisms in microRNAs and their target sites with human diseases and biological pathways. Nucleic Acids Res. 2014, 42, D86-D91. [CrossRef] [PubMed]

75. Gong, J.; Liu, C.; Liu, W.; Wu, Y.; Ma, Z.; Chen, H.; Guo, A.Y. An update of miRNASNP database for better SNP selection by GWAS data, miRNA expression and online tools. Database 2015, 2015, bav029. [CrossRef]

76. Borel, C.; Antonarakis, S.E. Functional genetic variation of human miRNAs and phenotypic consequences. Mamm. Genome 2008, 19, 503-509. [CrossRef] [PubMed]

77. Mencía, A.; Modamio-Høybjør, S.; Redshaw, N.; Morín, M.; Mayo-Merino, F.; Olavarrieta, L.; Aguirre, L.A.; del Castillo, I.; Steel, K.P.; Dalmay, T.; et al. Mutations in the seed region of human miR-96 are responsible for nonsyndromic progressive hearing loss. Nat. Genet. 2009, 41, 609-613. [CrossRef] [PubMed]

78. Iliff, B.W.; Riazuddin, S.A.; Gottsch, J.D. A single-base substitution in the seed region of miR-184 causes EDICT syndrome. Investig. Ophthalmol. Vis. Sci. 2012, 53, 348-353. [CrossRef]

79. Hu, H.; Li, J.; Zhang, J. Dysregulation of CD69 by overexpression of microRNA-367-3p associated with post-myocardial infarction cardiac fibrosis. Mol. Med. Rep. 2018, 18, 3085-3092. [CrossRef]

80. Van der Kwast, R.V.C.T.; Woudenberg, T.; Quax, P.H.A.; Nossent, A.Y. MicroRNA-411 and Its 5'IsomiR Have Distinct Targets and Functions and Are Differentially Regulated in the Vasculature under Ischemia. Mol. Ther. 2020, 28, 157-170. [CrossRef]

81. Moore, M.J.; Scheel, T.K.; Luna, J.M.; Park, C.Y.; Fak, J.J.; Nishiuchi, E.; Rice, C.M.; Darnell, R.B. miRNA-target chimeras reveal miRNA 3'-end pairing as a major determinant of Argonaute target specificity. Nat. Commun. 2015, 6, 8864. [CrossRef] [PubMed]

82. Broughton, J.P.; Lovci, M.T.; Huang, J.L.; Yeo, G.W.; Pasquinelli, A.E. Pairing beyond the Seed Supports MicroRNA Targeting Specificity. Mol. Cell 2016, 64, 320-333. [CrossRef] [PubMed]

83. Sheu-Gruttadauria, J.; Xiao, Y.; Gebert, L.F.; MacRae, I.J. Beyond the seed: Structural basis for supplementary microRNA targeting by human Argonaute2. EMBO J. 2019, 38, e101153. [CrossRef]

84. Baran-Gale, J.; Fannin, E.E.; Kurtz, C.L.; Sethupathy, P. Beta cell 5'shifted isomiRs are candidate regulatory hubs in type 2 diabetes. PLoS ONE 2013, 8, e73240. [CrossRef] 
85. Bofill-De Ros, X.; Yang, A.; Gu, S. IsomiRs: Expanding the miRNA repression toolbox beyond the seed. Biochim. Biophys. Acta (BBA) Bioenerg. 2020, 1863, 194373. [CrossRef] [PubMed]

86. Gebert, L.F.R.; MacRae, I.J. Regulation of microRNA function in animals. Nat. Rev. Mol. Cell Biol. 2019, 20, 21-37. [CrossRef]

87. Müller, M.; Fazi, F.; Ciaudo, C. Argonaute Proteins: From Structure to Function in Development and Pathological Cell Fate Determination. Front. Cell Dev. Biol. 2020, 7, 360. [CrossRef] [PubMed]

88. Meister, G.; Landthaler, M.; Patkaniowska, A.; Dorsett, Y.; Teng, G.; Tuschl, T. Human Argonaute2 mediates RNA cleavage targeted by miRNAs and siRNAs. Mol. Cell 2004, 15, 185-197. [CrossRef]

89. Park, M.S.; Phan, H.D.; Busch, F.; Hinckley, S.H.; Brackbill, J.A.; Wysocki, V.H.; Nakanishi, K. Human Argonaute3 has slicer activity. Nucleic Acids Res. 2017, 45, 11867-11877. [CrossRef]

90. Mercey, O.; Popa, A.; Cavard, A.; Paquet, A.; Chevalier, B.; Pons, N.; Magnone, V.; Zangari, J.; Brest, P.; Zaragosi, L.E.; et al. Characterizing isomiR variants within the microRNA-34/449 family. FEBS Lett. 2017, 591, 693-705. [CrossRef]

91. Burroughs, A.M.; Ando, Y.; de Hoon, M.J.; Tomaru, Y.; Suzuki, H.; Hayashizaki, Y.; Daub, C.O. Deep-sequencing of human Argonaute-associated small RNAs provides insight into miRNA sorting and reveals Argonaute association with RNA fragments of diverse origin. RNA Biol. 2011, 8, 158-177. [CrossRef]

92. Ye, J.; Xu, M.; Tian, X.; Cai, S.; Zeng, S. Research advances in the detection of miRNA. J. Pharm. Anal. 2019, 9, 217-226. [CrossRef] [PubMed]

93. Schamberger, A.; Orbán, T.I. 30 IsomiR species and DNA contamination influence reliable quantification of MicroRNAs by stem-loop quantitative PCR. PLoS ONE 2014, 9, e106315. [CrossRef] [PubMed]

94. Magee, R.; Telonis, A.G.; Cherlin, T.; Rigoutsos, I.; Londin, E. Assessment of isomiR discrimination using commercial qPCR methods. Non-Coding RNA 2017, 3, 18. [CrossRef] [PubMed]

95. Zhou, Y.; Huang, Q.; Gao, J.; Lu, J.; Shen, X.; Fan, C. A dumbbell probemediated rolling circle amplification strategy for highly sensitive microRNA detection. Nucleic Acids Res. 2010, 38, e156. [CrossRef] [PubMed]

96. Androvic, P.; Valihrach, L.; Elling, J.; Sjoback, R.; Kubista, M. Twotailed RT-qPCR: A novel method for highly accurate miRNA quantification. Nucleic Acids Res. 2017, 45, e144. [CrossRef]

97. Podini, D.; Vallone, P.M. SNP genotyping using multiplex single base primer extension assays. In Single Nucleotide Polymorphisms: Methods and Protocols; Komar, A.A., Ed.; Humana Press: Totowa, NJ, USA, 2009; pp. 379-391. [CrossRef]

98. Wang, S.; Zheng, Z.; Chen, P.; Wu, M. Tumor classification and biomarker discovery based on the $5^{\prime}$ isomiR expression level. BMC Cancer 2019, 19, 127. [CrossRef]

99. Sanchez Herrero, J.F.; Pluvinet, R.; Luna de Haro, A.; Sumoy, L. Paired-end small RNA sequencing reveals a possible overestimation in the isomiR sequence repertoire previously reported from conventional single read data analysis. BMC Bioinform. 2021, 22, 215. [CrossRef]

100. Zhang, Y.; Zang, Q.; Xu, B.; Zheng, W.; Ban, R.; Zhang, H.; Yang, Y.; Hao, Q.; Iqbal, F.; Li, A.; et al. IsomiR Bank: A research resource for tracking IsomiRs. Bioinformatics 2016, 32, 2069-2071. [CrossRef]

101. Liu, C.J.; Fu, X.; Xia, M.; Zhang, Q.; Gu, Z.; Guo, A.Y. miRNASNP-v3: A comprehensive database for SNPs and disease-related variations in miRNAs and miRNA targets. Nucleic Acids Res. 2021, 49, D1276-D1281. [CrossRef]

102. Bofill-De Ros, X.; Luke, B.; Guthridge, R.; Mudunuri, U.; Loss, M.; Gu, S. Tumor IsomiR Encyclopedia (TIE): A pancancer database of miRNA isoforms. Bioinformatics 2021, btab172. [CrossRef] [PubMed]

103. Telonis, A.G.; Magee, R.; Loher, P.; Chervoneva, I.; Londin, E.; Rigoutsos, I. Knowledge about the presence or absence of miRNA isoforms (isomiRs) can successfully discriminate amongst 32 TCGA cancer types. Nucleic Acids Res. 2017, 45, 2973-2985. [CrossRef]

104. Lan, C.; Peng, H.; McGowan, E.M.; Hutvagner, G.; Li, J. An isomiR expression panel based novel breast cancer classification approach using improved mutual information. BMC Med. Genom. 2018, 11, 118. [CrossRef] [PubMed]

105. Zhang, H.; Yang, S.; Guo, L.; Zhao, Y.; Shao, F.; Chen, F. Comparisons of isomiR patterns and classification performance using the rank-based MANOVA and 10-fold cross-validation. Gene 2015, 569, 21-26. [CrossRef]

106. Telonis, A.G.; Loher, P.; Jing, Y.; Londin, E.; Rigoutsos, I. Beyond the one-locus-one-miRNA paradigm: microRNA isoforms enable deeper insights into breast cancer heterogeneity. Nucleic Acids Res. 2015, 43, 9158-9175. [CrossRef]

107. Telonis, A.G.; Rigoutsos, I. Race Disparities in the Contribution of miRNA Isoforms and tRNA-Derived Fragments to TripleNegative Breast Cancer. Cancer Res. 2018, 78, 1140-1154. [CrossRef]

108. Salem, O.; Erdem, N.; Jung, J.; Münstermann, E.; Wörner, A.; Wilhelm, H.; Wiemann, S.; Körner, C. The highly expressed 5'isomiR of hsa-miR-140-3p contributes to the tumor-suppressive effects of miR-140 by reducing breast cancer proliferation and migration. BMC Genom. 2016, 17, 566. [CrossRef]

109. Bhardwaj, A.; Singh, H.; Trinidad, C.M.; Albarracin, C.T.; Hunt, K.K.; Bedrosian, I. The isomiR-140-3p-regulated mevalonic acid pathway as a potential target for prevention of triple negative breast cancer. Breast Cancer Res. 2018, 20, 150. [CrossRef] [PubMed]

110. Rhodes, L.V.; Martin, E.C.; Segar, H.C.; Miller, D.F.; Buechlein, A.; Rusch, D.B.; Nephew, K.P.; Burow, M.E.; Collins-Burow, B.M. Dual regulation by microRNA-200b-3p and microRNA-200b-5p in the inhibition of epithelial-to-mesenchymal transition in triple-negative breast cancer. Oncotarget 2015, 6, 16638-16652. [CrossRef] [PubMed]

111. Koi, Y.; Tsutani, Y.; Nishiyama, Y.; Ueda, D.; Ibuki, Y.; Sasada, S.; Akita, T.; Masumoto, N.; Kadoya, T.; Yamamoto, Y.; et al. Predicting the presence of breast cancer using circulating small RNAs, including those in the extracellular vesicles. Cancer Sci. 2020, 111, 2104-2115. [CrossRef] [PubMed] 
112. Mjelle, R.; Sjursen, W.; Thommesen, L.; Sætrom, P.; Hofsli, E. Small RNA expression from viruses, bacteria and human miRNAs in colon cancer tissue and its association with microsatellite instability and tumor location. BMC Cancer 2019, 19, 161. [CrossRef] [PubMed]

113. Babapoor, S.; Fleming, E.; Wu, R.; Dadras, S.S. A novel miR-451a isomiR, associated with amelanotypic phenotype, acts as a tumor suppressor in melanoma by retarding cell migration and invasion. PLoS ONE 2014, 9, e107502. [CrossRef]

114. Dika, E.; Broseghini, E.; Porcellini, E.; Lambertini, M.; Riefolo, M.; Durante, G.; Loher, P.; Roncarati, R.; Bassi, C.; Misciali, C.; et al. Unraveling the role of microRNA/isomiR network in multiple primary melanoma pathogenesis. Cell Death Dis. 2021, 12, 473. [CrossRef]

115. Londin, E.; Magee, R.; Shields, C.L.; Lally, S.E.; Sato, T.; Rigoutsos, I. IsomiRs and tRNA-derived fragments are associated with metastasis and patient survival in uveal melanoma. Pigment. Cell Melanoma Res. 2020, 33, 52-62. [CrossRef] [PubMed]

116. Koppers-Lalic, D.; Hackenberg, M.; de Menezes, R.; Misovic, B.; Wachalska, M.; Geldof, A.; Zini, N.; de Reijke, T.; Wurdinger, T.; Vis, A. Non-invasive prostate cancer detection by measuring miRNA variants (isomiRs) in urine extracellular vesicles. Oncotarget 2016, 7, 22566-22578. [CrossRef]

117. Agrawal, R.; Pandey, P.; Jha, P.; Dwivedi, V.; Sarkar, C.; Kulshreshtha, R. Hypoxic signature of microRNAs in glioblastoma: Insights from small RNA deep sequencing. BMC Genom. 2014, 15, 686. [CrossRef] [PubMed]

118. Ma, M.; Yin, Z.; Zhong, H.; Liang, T.; Guo, L. Analysis of the expression, function, and evolution of miR-27 isoforms and their responses in metabolic processes. Genomics 2019, 111, 1249-1257. [CrossRef]

119. Ibuki, Y.; Nishiyama, Y.; Tsutani, Y.; Emi, M.; Hamai, Y.; Okada, M.; Tahara, H. Circulating microRNA/isomiRs as novel biomarkers of esophageal squamous cell carcinoma. PLOS ONE 2020, 15, e0231116. [CrossRef]

120. Ni, H.; Dai, X.; Leng, X.; Deng, M.; Qin, Y.; Ji, Q.; Xu, C.; Li, J.; Liu, Y. Higher variety and quantity of microRNA-139-5p isoforms confer suppressive role in hepatocellular carcinoma. J. Cell. Biochem. 2018, 119, 6806-6813. [CrossRef]

121. Swierniak, M.; Wojcicka, A.; Czetwertynska, M.; Stachlewska, E.; Maciag, M.; Wiechno, W.; Gornicka, B.; Bogdanska, M.; Koperski, L.; de la Chapelle, A. In-depth characterization of the microRNA transcriptome in normal thyroid and papillary thyroid carcinoma. J. Clin. Endocrinol. Metab. 2013, 98, E1401-E1409. [CrossRef]

122. Saito, K.; Inagaki, K.; Kamimoto, T.; Ito, Y.; Sugita, T.; Nakajo, S.; Hirasawa, A.; Iwamaru, A.; Ishikura, T.; Hanaoka, H.; et al. MicroRNA-196a is a putative diagnostic biomarker and therapeutic target for laryngeal cancer. PLoS ONE 2013, 8, e71480. [CrossRef]

123. Chang, H.T.; Li, S.C.; Ho, M.R.; Pan, H.W.; Ger, L.P.; Hu, L.Y.; Yu, S.Y.; Li, W.H.; Tsai, K.W. Comprehensive analysis of microRNAs in breast cancer. BMC Genom. 2012, 13, S18. [CrossRef] [PubMed]

124. Wu, X.; Zeng, R.; Wu, S.; Zhong, J.; Yang, L.; Xu, J. Comprehensive expression analysis of miRNA in breast cancer at the miRNA and isomiR levels. Gene 2015, 557, 195-200. [CrossRef] [PubMed]

125. Muller, H.; Marzi, M.J.; Nicassio, F. IsomiRage: From Functional Classification to Differential Expression of miRNA Isoforms. Front. Bioeng. Biotechnol. 2014, 2, 38. [CrossRef] [PubMed]

126. Guo, Y.; Yu, H.; Wang, J.; Sheng, Q.; Zhao, S.; Zhao, Y.Y.; Lehmann, B.D. The Landscape of Small Non-Coding RNAs in Triple-Negative Breast Cancer. Genes 2018, 9, 29. [CrossRef]

127. Kozubek, J.; Ma, Z.; Fleming, E.; Duggan, T.; Wu, R.; Shin, D.G.; Dadras, S.S. In-depth characterization of microRNA transcriptome in melanoma. PLoS ONE 2013, 8, e72699. [CrossRef]

128. Magee, R.G.; Telonis, A.G.; Loher, P.; Londin, E.; Rigoutsos, I. Profiles of miRNA Isoforms and tRNA Fragments in Prostate Cancer. Sci. Rep. 2018, 8, 1-13. [CrossRef]

129. Leung, C.M.; Li, S.C.; Chen, T.W.; Ho, M.R.; Hu, L.Y.; Liu, W.S.; Wu, T.T.; Hsu, P.C.; Chang, H.T.; Tsai, K.W. Comprehensive microRNA profiling of prostate cancer cells after ionizing radiation treatment. Oncol. Rep. 2014, 31, 1067-1078. [CrossRef]

130. Guo, Y.; Strickland, S.A.; Mohan, S.; Li, S.; Bosompem, A.; Vickers, K.C.; Zhao, S.; Sheng, Q.; Kim, A.S. MicroRNAs and tRNA-derived fragments predict the transformation of myelodysplastic syndromes to acute myeloid leukemia. Leuk Lymphoma 2017, 58, 2144-2155. [CrossRef]

131. Wallaert, A.; Van Loocke, W.; Hernandez, L.; Taghon, T.; Speleman, F.; Van Vlierberghe, P. Comprehensive miRNA expression profiling in human T-cell acute lymphoblastic leukemia by small RNA-sequencing. Sci. Rep. 2017, 7, 1-8. [CrossRef]

132. Dawidowska, M.; Jaksik, R.; Drobna, M.; Bronisława Zawadzka, S.; Kosmalska, M.; Sędek, L.; Machowska, L.; Lalik, A.; Lejman, M.; Ussowicz, M.; et al. Comprehensive Investigation of miRNome Identifies Novel Candidate miRNA-mRNA Interactions Implicated in T-Cell Acute Lymphoblastic Leukemia. Neoplasia 2019, 21, 294-310. [CrossRef]

133. Agnelli, L.; Bisognin, A.; Todoerti, K.; Manzoni, M.; Taiana, E.; Galletti, S.; Cutrona, G.; Gaffo, E.; Bortoluzzi, S.; Neri, A. Expanding the repertoire of miRNAs and miRNA-offset RNAs expressed in multiple myeloma by small RNA deep sequencing. Blood Cancer J. 2019, 9, 21. [CrossRef]

134. Loher, P.; Londin, E.R.; Rigoutsos, I. IsomiR expression profiles in human lymphoblastoid cell lines exhibit population and gender dependencies. Oncotarget 2014, 5, 8790-8802. [CrossRef]

135. Guo, L.; Zheng, L.; Zhao, Y.; Wang, Q. Biomed Profiling and Bioinformatic Analyses Indicate Differential circRNA and miRNA/isomiR Expression and Interactions. BioMed Res. Int. 2018, 2018, 8518563. [CrossRef] [PubMed]

136. Li, S.C.; Liao, Y.L.; Ho, M.R.; Tsai, K.W.; Lai, C.H.; Lin, W.C. miRNA arm selection and isomiR distribution in gastric cancer. BMC Genom. 2012, 13, S13. [CrossRef] [PubMed] 
137. Berardocco, M.; Radeghieri, A.; Busatto, S.; Gallorini, M.; Raggi, C.; Gissi, C.; D’Agnano, I.; Bergese, P.; Felsani, A.; Berardi, A.C. RNA-seq reveals distinctive RNA profiles of small extracellular vesicles from different human liver cancer cell lines. Oncotarget 2017, 8, 82920-82939. [CrossRef] [PubMed]

138. Saiselet, M.; Gacquer, D.; Spinette, A.; Craciun, L.; Decaussin-Petrucci, M.; Andry, G.; Detours, V.; Maenhaut, C. New global analysis of the microRNA transcriptome of primary tumors and lymph node metastases of papillary thyroid cancer. BMC Genom. 2015, 16, 828. [CrossRef] [PubMed]

139. Parafioriti, A.; Cifola, I.; Gissi, C.; Pinatel, E.; Vilardo, L.; Armiraglio, E.; Di Bernardo, A.; Daolio, P.A.; Felsani, A.; D’ Agnano, I.; et al. Expression profiling of microRNAs and isomiRs in conventional central chondrosarcoma. Cell Death Discov. $2020,6,46$. [CrossRef] 